\title{
Unprecedented pluri-decennial increase in the growing stock of French forests is persistent and dominated by private broadleaved forests
}

\author{
Jean-Daniel Bontemps ${ }^{1}$ (D) $\cdot$ Anaïs Denardou ${ }^{1,2} \cdot$ Jean-Christophe Hervé $^{1} \cdot$ Jean $^{\text {Bir }^{3}}$ - Jean-Luc Dupouey ${ }^{2}$
}

Received: 27 March 2020 / Accepted: 14 September 2020 / Published online: 12 October 2020

(C) INRAE and Springer-Verlag France SAS, part of Springer Nature 2020

\begin{abstract}
- Key message French forests exhibit the fastest relative changes across Europe. Growing stock increases faster than area, and is greatest in low-stocked private broadleaved forests. Past areal increases and current GS levels show positive effects on GS expansion, with GS increases hence expected to persist.

- Context Strong increases in growing stocks (GS) of European forests for decades remain poorly understood and of unknown duration. French forests showing the greatest relative changes across Europe form the investigated case study.

- Aims The magnitudes of net area, GS, and GS density (GSD) changes were evaluated across forest categories reflecting forest policy and land-use drivers. The roles of forest areal changes, GS and GSD levels on GS changes were investigated.

- Methods National Forest Inventory data were used to produce time series of area, GS and GSD across forest categories over 1976-2014, and exploratory causal models of GS changes.

- Results GS (+57\%) increased three times faster than area, highlighting an advanced stage in the forest transition. Low-stocked private forests exhibited strong changes in GS/GSD, greatest in private broadleaved forests, stressing the contribution of returning forests on abandoned lands. Regression models demonstrated positive effects of both past areal increases and current GS, on GS expansion.
\end{abstract}

- Conclusion Aerial C-sink in French forests is expected to persist in future decades.

Keywords Forest transition $\cdot$ Forest expansion $\cdot$ National forest inventory $\cdot$ Area $\cdot$ Returning forests $\cdot$ Carbon stock

Jean-Christophe Hervé passed away on April 16th 2017

Handling Editor: Andreas Bolte

Contribution of the co-authors H.J.-C. played a seminar role in the exploration of this topic; B.J.-D., H.J.-C., D.J.-L. and D.A. conceived and designed the analyses; D.A. performed the analyses; D.A., B.J.-D., D.J.-L. analyzed the data; B.J. contributed to the data, their use and their interpretation; D.A, B.J.-D., D.J.-L. wrote the paper. B.J.-D. submitted the manuscript and conducted the revisions of the manuscript.

Jean-Daniel Bontemps

Jean-Daniel.Bontemps@ign.fr

Anaïs Denardou

anais.denardou@gmail.com

Jean Bir

Jean.Bir@ign.fr

Jean-Luc Dupouey

jean-luc.dupouey@inra.fr
1 IGN, Laboratoire d'Inventaire Forestier (LIF), 14 rue Girardet, 54000 Nancy, France

2 Université de Lorraine, AgroParisTech, INRA, UMR, 1434 Silva, 54000 Nancy, France

3 IGN, Service de l'inventaire forestier et environnemental, Château des Barres, 45290 Nogent-sur-Vernisson, France 


\section{Introduction}

After centuries of decrease, the forest area of most developed countries has increased over at least recent decades (Meyfroidt and Lambin 2011), a phenomenon termed "forest transition" (Mather 1992; Rudel et al. 2010) that partly finds root in agricultural land abandonment (Keenleyside and Tucker 2010). While the volume of the growing stock (GS) is a major forest attribute, encompassed in the concept of "forest identity" (an analytic decomposition of forest status according to four state variables including area, volume, biomass, and carbon, Kauppi et al. 2006), little focus has been placed on describing its temporal course. Statistics on European forests (EU-28) reveal net recent increases (i.e. resulting difference between gains and losses) in both forest area and GS, more intense for the latter $(+0.35 \%$ /year for area and $+1.33 \%$ /year for GS between 1990 and 2015; FAO 2015), with this European regional trend being globally unique. European forests are also the most intensively harvested (1.7\% of the GS harvested every year), indicating the importance of the current forest regrowth after extended periods of intense depletion of wood resources (Mather 2001; Glatzel 1999).

Increase in forest GS results from both the addition of new forests through area extension and the densification of forests. Forest densification depends on the balance between growth, harvest, and natural mortality. Many drivers control this balance, including low-intensity or inexistent management, growth recovery after decades of forest fertility depletion (Glatzel 1999), plantation of fast-growing species of improved genetic provenances, and development of new forests on previous farmlands with improved soil fertility (Koerner et al. 1997). Furthermore, the increase in forest growth induced by anthropogenic changes in atmospheric deposition of nitrogen and $\mathrm{CO}_{2}$ concentration (Kahle et al. 2008; Bontemps et al. 2011) as well as climatic change (Boisvenue and Running 2006; Charru et al. 2017) might significantly impact the growing stock (Henttonen et al. 2017). Climate change has also started playing a role in tree mortality (Senf et al. 2018, Taccoen et al. 2019).

Major societal issues are associated with this increase in the forest growing stock, including options for the more intensive use of wood resources and substitution for fossil fuels in the European bio-economy strategy perspective (European commission 2015) or for increased carbon sequestration (Houghton et al. 1999; Rhemtulla et al. 2009; Li et al. 2016). The extent to which GS increases are steady and will maintain in the future is, therefore, of primary concern. Yet, knowledge and theoretical predictions on the temporal course of GS remain very limited. Nabuurs et al. (2013) reported first signs of saturation in the carbon sink of European forests, especially in Western Europe. Conflicting this view, changes in GS between 1990 and 2015 across European countries
(Forest Europe 2015) show a strong positive correlation with GS in 1990, suggesting that countries with a large GS tend to present greater GS increases. Moreover, the correlation with GS density (volume of the growing stock per hectare, GSD) is only slightly negative $(-0.34 ; p<0.1)$. Both aspects suggest that running down of GS increase is implausible in the near future.

As a major cause of the knowledge gap regarding longterm GS changes, comprehensive and consistent forest data over the long term are lacking. Statistical national forest inventories (NFI) were initiated in the 1920s in European boreal countries, most advanced in the field, and were subsequently set up in other industrialized countries up to the very recent present, and often with historical methodological changes (Tomppo et al. 2010). In addition, large-scale forecasting models of timber development face important difficulties to deliver reliable predictions on European forests in a nonstationary dynamic and climatic change context (Sällnas et al. 2015; Barreiro et al. 2017). Therefore, long-term and country-scale insights into GS expansion have been delivered for very few countries (Sweden in Egnell et al. 2011; Finland in Henttonen et al. 2017; USA in Smith et al. 2004). The onset of NFI programs in Europe is however facilitating the analysis of this issue over a few decades, especially in France (Pignard 2000). Further, their coverage of both forest area and GS dynamics is crucial for the appraisal of forest dynamic stages (Kauppi et al. 2006).

Among European countries (EU-28), French forests have shown the strongest increases in both forest area $(+110,000 \mathrm{ha} /$ year, together with those in Spain; Forest Europe 2015) and GS (+35 million cubic meters per year, or $\mathrm{hm}^{3} /$ year) over the last decade (2005-2015), forming a demonstrative case study of wood accumulation. France was also the seminal case study for Mather's theory of forest transition (Mather et al. 1999). Like many European countries (Kauppi et al. 2018), GS shows a relative increase greater than that of forest area (+ 1.3\%/year between 2005 and 2015 compared with $+0.65 \%$ /year for area; Forest Europe 2015). This suggests that forest densification plays a significant role in this increase, a process to be urgently recognized in forest dynamic and $\mathrm{C}$ sequestration appraisal (Kauppi et al. 2006; Rautiainen et al. 2011). While GS has probably doubled over the past 50 years (Hervé et al. 2014), ancient forest area statistics (Daubree 1912) suggest forest areal increase by $60 \%$ over the twentieth century (Denardou et al. 2017). In 1990, forests in France hence had the second greatest forest carbon stock among the EU-27 (734 Tg C; Karjalainen et al. 2003) after Sweden (904 Tg C) and close to Germany (712 Tg C) whose greater GS is offset by the importance of softwoods in these forests.

Possible causes of wood accumulation are related to land use, forest planning, and forest policy issues. First, the French territory has a long-lasting agricultural history, and a current 
utilized agricultural area of $>50 \%$ for an afforested area of $31 \%$, among the lowest in Europe (Forest Europe 2015), a situation prone to forest areal expansion over agricultural lands. A significant part of the French agricultural area is composed of poor lands of restricted agricultural interest and thus subjected to abandonment, especially in mountainous and Mediterranean ranges (MacDonald et al. 2000; Abadie et al. 2017). Second, private forest ownership dominates the French forests, representing more than $75 \%$ of the forested area, and private forests have gained over agricultural estates smaller than 50 ha, particularly in the central mountain range of France ("Massif Central"; Normandin 1979), affected for long by land abandonment. In contrast to public forests, private forests are not subjected to legally binding management plans fostering harvest planning, and only $23 \%$ of the private forest area are covered by a management plan (Boutefeu 2005). Finally, afforestation, mostly with conifers, has been favoured by recurrent forest policy programs throughout the twentieth century, including e. g. the post-war national forest fund program "Fonds Forestier National" (FFN; Pourtet 1972; Dodane 2009) that had been running from 1946 to 1999 and amounted to $c a 800,000$ ha of net afforestation (Dodane 2009).

Unfortunately, heterogeneities in the GS increases remain uncovered to date, as international reporting (State of Europe's forests; Forest Europe 2015, global FRA report; FAO 2015) delivers only country-scale and present status statistics. The partitioning of forest expansion according to factors such as geographic location, forest ownership, and tree species composition is therefore bound to bring additional cognitive view of this forest expansion. In France, spatial variations of GS changes may primarily reflect land-use determinants of forest changes (e.g. privileged expansion in marginal agricultural lands; MacDonald et al. 2000; Strijker 2005). Ownership-driven variations may result from distinct forest management strategies (e.g. lower harvest of wood in smallsized private forests; Schmithüsen and Hirsch 2010). Last, tree species composition-oriented analyses may reveal maturation in afforested coniferous forests in Europe over the twentieth century (Dedrick et al. 2007). Pignard (2000) explored areal, GS, and GSD changes in French forests over one decade (1980-1990), and observed large increases in the area of broadleaved forests, and great increases in GS and GSD in private forests.

The present study has two objectives: (1) quantify net area and GS changes over nearly 40 years (1976-2014) and explore their heterogeneity and dependence onto forest ownership, composition, and geographic location (NUTS-3 department units), (2) investigate how GS changes over a period quantitatively depend on previous areal changes and initial GS and GSD, using regression models intended to produce a process-oriented understanding of these dynamics.

\section{Materials and methods}

\subsection{Material}

Data from the French national forest inventory (NFI) were used, the collection of which began in 1961 (Hervé 2016). The inventory was based on temporary plots, collected around every 10 years at "department" administrative unit (dau, NUTS-3 units of the European Community) and asynchronously between dau. It has turned systematic and annual since 2005, with a 1/10th sampling effort of the former method consented every year as a counterpart on field operation efforts.

Field plot inventory is operated in "production" forests (i.e. forests where no constraint hampers the potential harvest of wood; Hervé 2016, equivalent to forest available for wood supply of the UN/FAO), representing $95 \%$ of the total forest area in 2010 (16.4 million ha according to the FAO definition). This proportion has been steady since 1980. Nonproductive forests are thus excluded from field inventory. Yet, their steady proportion since 1980 makes them of secondary importance for the present purpose. Poplar plantations were neither covered by the analysis, as they were not classified as 'production' forests before $2005(<200,000$ ha, i.e. $<$ $1.2 \%$ of the total production forest area). Forests in our study ultimately represent $94 \%$ of the current total forested area. Of major importance to the reliability of the study: i) the definition of the forest growing stock and measurement protocols did not change between the two inventory periods (2005), ii) albeit close, the forest area definitions differed and were homogenized with a final uncertainty below $1 \%$ of the total forest area, iii) tree species composition appraisal changed in a way that prohibited homogenisation (Denardou 2019), leading to restrict the study period to 1987-1994. Yet, relative indicators of expansion, less sensitive to homogenisation issues, were derived for the sake of comparison over 20062014. More information about the data used (definitions of forest area and GS, data selection, and reference period) and inference methods are available in Annex 1.

\subsection{Investigated forest strata}

Forests were partitioned according to three factors, including a discretization of space (90 dau units, NUTS-3, each covering between 3000 and $10,000 \mathrm{~km}^{2}$ ), ownership of property (hereafter "ownership"), and dominant tree species composition (coniferous or broadleaved species).

Ownership comprises three categories: State's forests, other public forests (OPF, belonging to municipalities, and anecdotally to other local public authorities), and private forests. State's forests and most OPF hold a public management plan framed by the forest law (the so-called "forest regime") and are identified from maps by the NFI. Unlike in private forests, 
the dynamics of public forests is therefore constrained by legal recognition processes and extension policies. Other few OPF without any management plan at the date of inventory are classified as private forests. In spite of strong heterogeneities in the private forest ownership structure and management objectives (Petucco et al. 2015), current unavailability of public information on forest management plans did not allow split the analyses further.

Tree species composition was differentiated in two categories and describes the dominant botanic class (defined from tree crown projection on the ground in inventory plots), i.e. broadleaved or coniferous-dominated forests. Composition is not described in NFI plots with canopy cover rate $<10 \% / 15 \%$ (ancient/recent methods), which represented $8 \%$ of the total forest production area, but only $0.3 \%$ of the total GS on average over 2006-2014. Accordingly, these forests were discarded from the analyses involving this compositional attribute. Moreover, data for species composition from the first dau inventories were not available.

In this study, the term "stratum" was used to designate a forest category defined by either a one-factor level (e.g. private forests) or crossed-factor levels (e.g. the State's broadleaved forests).

\subsection{Patterns and magnitude of forest changes in area and growing stock (objective 1)}

Net changes in forest area, GS, and GSD were estimated from data including the two inventory methods (before and after 2005, see 2.1) in order to provide the longest possible view on forest expansion. The analysis of net changes in these variables implies that no overview on afforestation/deforestation processes, nor on areal fluxes resulting from possible changes in dominating forest composition is provided.

Since the NFI was asynchronously conducted by dau before 2005, linear interpolations of dau-based area and GS data were performed and annualized, and aggregated across strata when needed. GSD (growing stock density) was calculated as the ratio between forest GS and forest area after interpolation, using the standard and robust "ratio of means" approach (Annex 1).

The origin of the study period was defined conservatively as the year from which $80 \%$ of the dau had already been inventoried at least once (i.e. 1976). For all forest attributes, the endpoint of the interpolations was an average of annual 2006-2014 forest estimates (median year 2010), computed to increase their statistical precision. The total study period was therefore 1976-2014. Owing to data availability and homogeneity over years, the study period of analyses involving the compositional attribute was restricted to 1987-1994, with some additional indicators provided over 2006-2014 for assessing the stability of conclusions.
Bilateral confidence intervals at a 95\% level for the annual area and GS were calculated using bootstrap sampling in the published distributions of sampling uncertainty in NFI estimates as soon as these errors were documented (Annex 2).

Mean differences in area, GS, and GSD between 2010 and 1976 (or 1994 and 1987 for ownership $\times$ composition analysis) across the whole country's forests (unique stratum), ownership-related strata, or ownership $\times$ composition strata were tested against zero using classical paired $t$ tests. Interpolated estimates over dau units belonging to these strata at the two dates formed the respective samples used for testing. Of note, the different tests were performed onto distinct strata and sets of dau units (determined by ownership, or ownership $\times$ composition) that therefore form independent populations, producing independent tests. Maps of forest changes were also generated at a dau resolution.

To quantify inequality in forest changes among ownership and composition strata, we calculated the ratio ( $\mathrm{R}_{\mathrm{S}}$, unitless) of the relative importance of the stratum in the countrywide change (fraction of the total absolute flux of area or GS associated to the stratum, i.e. fraction of the expansion, or PC) to the countrywide initial relative importance of the stratum (P0, initial percentage in the forest).

$\mathrm{R}_{\mathrm{s}}=\mathrm{PC}_{\mathrm{s} /} \mathrm{PO}_{\mathrm{s}}$

$\mathrm{PC}_{\mathrm{s}}=\Delta \mathrm{X}_{\mathrm{s}} / \Delta \mathrm{X}_{\text {tot }}$

$\mathrm{P} 0_{\mathrm{s}}=\mathrm{X} 0_{\mathrm{s}} / \mathrm{X} 0_{\text {tot }}$

with $\mathrm{R}_{\mathrm{s}}$, the ratio of the stratum $\mathrm{s}, \mathrm{PC}_{\mathrm{s}}$, the percentage of total change associated to the stratum $\mathrm{s}, \mathrm{P} 0_{\mathrm{s}}$, the initial percentage of the forest in the stratum $\mathrm{s}, \Delta \mathrm{X}_{\mathrm{s}}$ the absolute area or GS change in the stratum $\mathrm{s}, \Delta \mathrm{X}_{\text {tot }}$ the area or GS change in the total forest, $\mathrm{X} 0_{\mathrm{s}}$ the initial area or GS of the stratum, and $\mathrm{X} 0_{\text {tot }}$ the initial area or GS of the whole French metropolitan forest.

Values of $\mathrm{R}$ greater than one (resp. lower than one) indicate a stratum contribution more (resp. less) than proportional to its initial importance in the forest. Consequently, the relative importance of strata with $R>1$ (resp. $<1$ ) increases (resp. decreases) in the forest over the study period.

\subsection{Effects of forest area and volume attributes on GS changes (objective 2)}

The influence of some forest status and dynamics attributes on GS changes were explored using a multiple regression modelling approach within the forest stratifications under study in order to test a few specific hypotheses (see below). The purpose was to screen for effects of forest attributes and their direction, significance, and magnitude of influence, and not to elaborate a full predictive model of GS changes, unrealistic at this modelling scale. Also, since the French NFI plots are temporary, forest changes cannot be inferred at the plot level, 
but only on statistically representative forest domains (strata). Due to the dau-driven implementation of forest inventory, the statistical units used in the regression models were the between-inventory periods of each dau (or BIP). In 2009, a storm ("Klaus") had an important impact on the French forest GS. Then, BIP most impacted by the Klaus storm were discarded.

The explanatory variables included: i) the total initial growing stock of the unit $\left(\mathrm{GS}_{\mathrm{i}}\right)$, hypothesised to contribute to the GS changes through a "law of mass action" or capitalproduction paradigm (Berryman 1992), ii) the initial growing stock density of the unit $\left(\mathrm{GSD}_{\mathrm{i}}\right)$, hypothesised to capture the density-dependence of GS changes, and iii) total recent increases in forest area over the one or two previous BIP $\left(\Delta \mathrm{S}_{-1}\right.$ and $\left.\Delta \mathrm{S}_{-2}\right)$, which were tested for their possible delayed contribution to the growing stock. Since only past areal increases can have a delayed effect on current GS changes, past negative changes in forest area (that affect past - not current - GS change) were set to 0 . By contrast, decreases in forest area concomitant to the studied BIP $(\Delta \mathrm{S}$, set to 0 for positive values) were tested as they immediately induce a reduction in GS. Since the timespan $(\Delta t)$ of BIP is not constant, all these effects - except that of current decreases in area-were figured out as proportional to $\Delta \mathrm{t}$. The simple effect of the BIP timespan $(\Delta t)$ was also tested.

Statistically, the associated model is written as a stochastic process:

$$
\begin{aligned}
\Delta \mathrm{GS}= & \mathrm{a} \Delta \mathrm{t}+\mathrm{b} \mathrm{GS}_{\mathrm{i}} \Delta \mathrm{t}+\mathrm{c} \mathrm{GSD}_{\mathrm{i}} \Delta \mathrm{t} \\
& +\mathrm{d}_{\Delta \mathrm{S}-1>0} \Delta \mathrm{S}_{-1} \Delta \mathrm{t}+\mathrm{e}_{\Delta \mathrm{S}-2>0} \Delta \mathrm{S}_{-2} \Delta \mathrm{t} \\
& +\mathrm{f}_{\Delta \mathrm{S}<0} \Delta \mathrm{S}+\varepsilon
\end{aligned}
$$

where the error, $\varepsilon$, is a stochastic component assumed to be Gaussian and prone to depend on $\Delta \mathrm{t}$ and other predictors.

The alternative option of factoring out $\Delta \mathrm{t}$ and model $\Delta \mathrm{GS} /$ $\Delta \mathrm{t}$ was not retained, as $\varepsilon$ was found to depend on $\mathrm{GS}_{\mathrm{i}}$ in preliminary explorations. Heteroskedasticity was thus handled using a generalized least-square (GLS) fitting criterion allowing the variance of $\varepsilon, V(\varepsilon)$, to be modelled as a function of $\mathrm{GS}_{\mathrm{i}}$. A model of residual variance proportional to $\mathrm{GS}_{\mathrm{i}}$ was found best suited to data $\left(V[\varepsilon] \propto \mathrm{GS}_{\mathrm{i}}\right)$. Since models were formulated at a wide spatial scale (dau, of an area up to $10,000 \mathrm{~km}^{2}$ ) and applied to a discrete irregular tessellation of the territory, it was not possible to screen for local continuous spatial autocorrelation in the errors. Last, a prior correlation analysis between predictors revealed inexistent to moderate correlation structures, thus not requiring to handle multicollinearity (see Annex Table 5).

Models were fitted on two nested datasets, one first using $\Delta \mathrm{S}_{-1}$ only $(188 \mathrm{BIP})$ and one second including both $\Delta \mathrm{S}_{-1}$ and $\Delta \mathrm{S}_{-2}$ (99 BIP). Models were fitted on the full dataset or by ownership and ownership $\times$ composition strata, which are independent. Models including $\Delta \mathrm{S}_{-2}$ are summarized in Annex Table 6.

All data analyses were performed using the $\mathrm{R}$ software ( $\mathrm{R}$ Core Team 2017). Models fitted with a GLS criterion were performed with the $g l s$ function of nlme package.

\section{Results}

\subsection{Patterns and magnitude of forest changes in area and growing stock (objective 1)}

\subsubsection{Country-scale forest changes}

Over the study period, total forest area and GS increased by 17 and $57 \%$, respectively $\left(+2.3\right.$ million ha and $+906 \mathrm{hm}^{3}$, or $10^{9} \mathrm{~m}^{3}$; Fig. 1). The relative increase in GS was thus more than three-fold greater than that in area, leading to an increase in GSD by $+34 \%$ (shifting from 121 to $162 \mathrm{~m}^{3} / \mathrm{ha}$ ). Confidence envelopes were narrow in view of the ongoing forest changes detected (Fig. 1), indicating that the NFI sampling errors did not jeopardize the detection of forest changes over the period (wider envelopes at the end of the study period result from reduced sampling effort, see 2.1). Almost all dau showed an increase in forest area, GS and GSD (Fig. 2; $p<10^{-10}$ in both cases), highlighting the widespread nature of these forest changes across the territory.

Maps (Fig. 2) revealed strongly spatially structured heterogeneities in these forest changes. These differed between area and GS and, therefore, indicated spatial separation of forest areal extension and GS densification processes. Areal changes were greatest in Southern and Northwestern France, followed by the Central Mountain range. In comparison, the greatest increases in GS and GSD occurred in the Central Mountain range and central North (Fig. 2). This finding supported the hypothesis of temporal changes in the geography of forest area extension.

\subsubsection{Forest changes across ownership strata}

Ownership was a major partitioning factor of forest changes (Table 1). Private forests showed the greatest absolute increases in area and growing stock $(+1.800$ million ha and + $770 \mathrm{hm}^{3} ; p<10^{-10}$ ), as a first logical outcome of their prevalence over the territory. State's forests, subjected to mandatory forest planning for almost two centuries (Boutefeu 2005), showed the smallest forest changes $(+0.080$ million ha and $+20 \mathrm{hm}^{3} ; p<0.04$; Table 1; Fig. 3). OPF occupied an intermediate position $\left(p<10^{-7}\right)$. Private forests subjected to nonconstraining management plans beyond 25 ha in size since the 1960s also showed the greatest increase in GSD, shifting from 104 to $155 \mathrm{~m}^{3}$ /ha over the period (Table 1; Fig. 3). GSD in State's forests, greater than in any other ownership category 

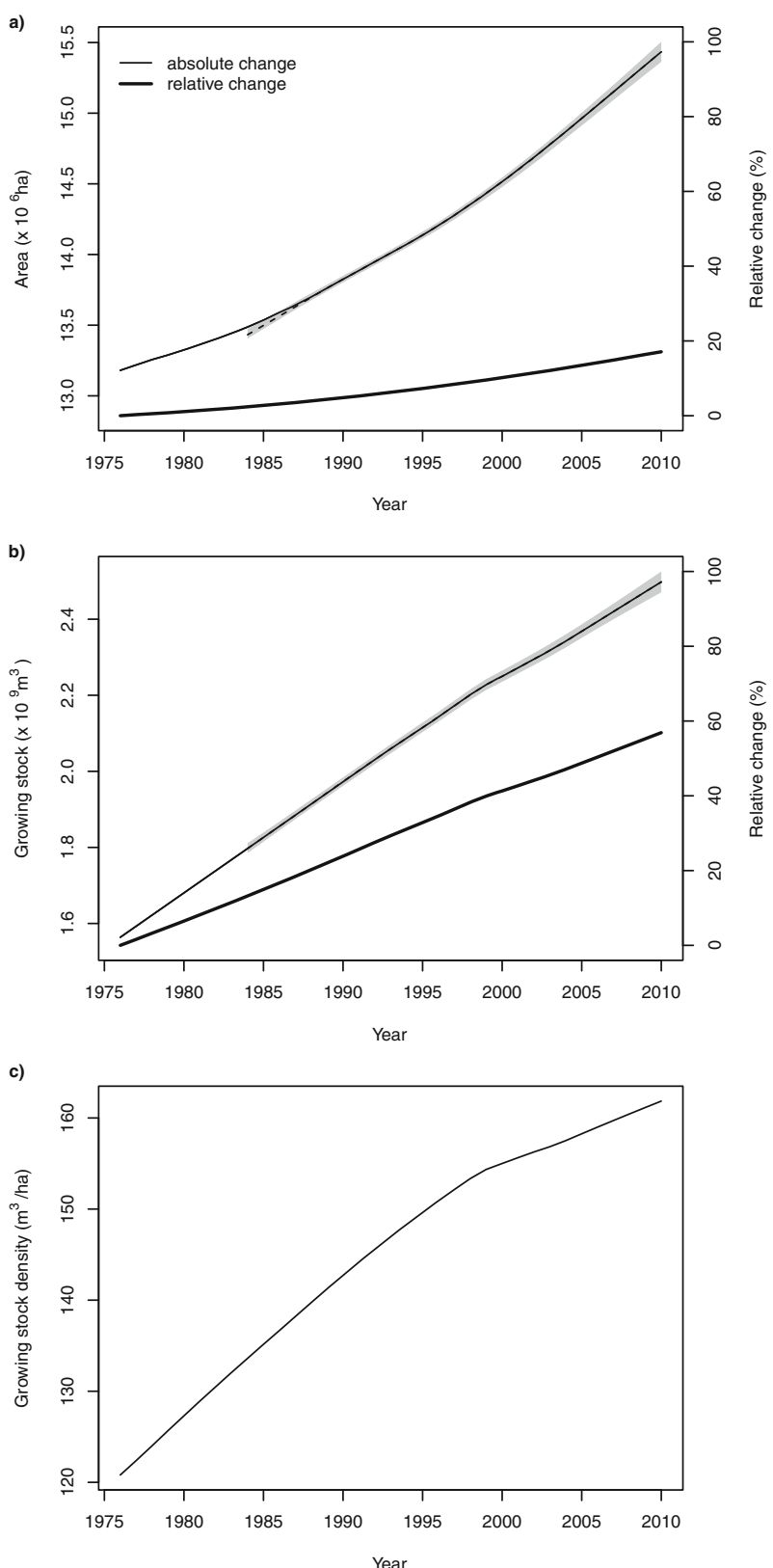

Fig. 1 Absolute and relative trajectories of forest a) area, b) volume of the growing stock and c) growing stock density in French forests over the period 1976-2010. Relative changes are expressed as percentages of 1976 estimates. Only the absolute changes were represented for GSD. Volumes are defined on standing trees inventoried from $7.5 \mathrm{~cm}$ over bark at dbh (1.30 m height) and describe stem volume up to a final diameter of $7 \mathrm{~cm}$. The $95 \%$ bilateral confidence intervals were established using 10,000 bootstrap samples taken from the NFI estimates of sampling errors and are represented in grey (Annex 2). The dashed line in (a) represents the interpolated chronology from inventories enabling the bilateral confidence interval calculation (errors on the first inventories were not available)

(above $180 \mathrm{~m}^{3} / \mathrm{ha}$ ), remained almost constant. From a spatial perspective, private forests showed positive changes in area, GS, and GSD for almost all dau, again highlighting a widespread dynamic in this ownership category (Annex Fig. 6)
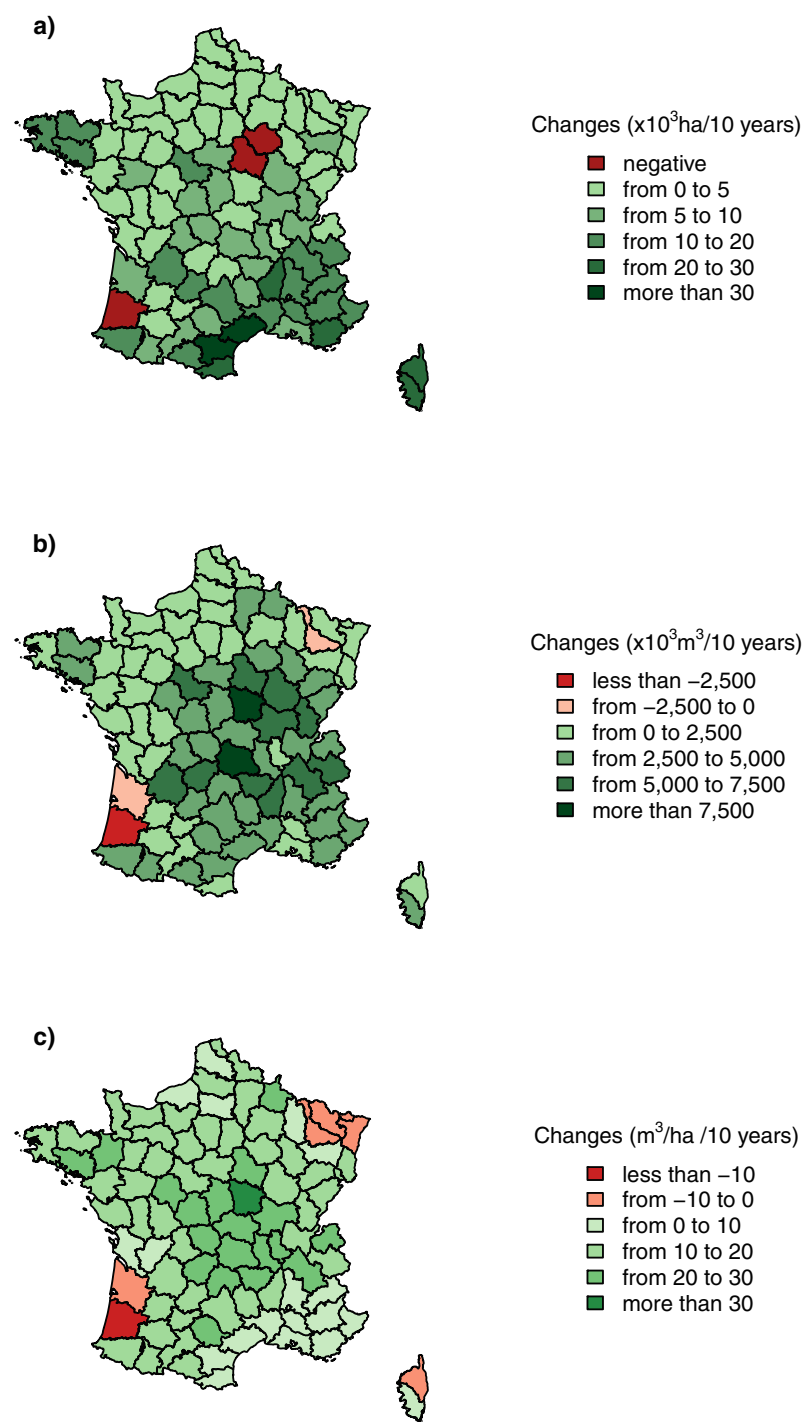

Fig. 2 Maps of decennial changes in a area, b volume of the growing stock, and c growing stock density in French forests across department administrative units (dau) over the period 1976-2010

and, regardless of their prevalence, much greater in halfEastern France. In contrast, State's forests, and to a lesser extent $\mathrm{OPF}$, more frequently exhibited negative changes in these attributes across the territory.

Private forests and OPF showed the same relative changes in area $(+19 \%$ for private forests and $+18 \%$ for OPF). Noticeably, the relative increase in GS was four-fold (resp. two-fold) greater than that in area in private forests (resp. in OPF), whereas they were of a similar magnitude in State's forests (Table 1). This highlighted the intensity of forest densification in private forests. In this order, private forests, OPF, and State's forests showed changes of decreasing relative magnitude and contribution to total changes ( $R$ ratio) in area and GS (Table 1). Furthermore, private forests were the only forests to exhibit a greater contribution to total GS change ( $85 \%, R=1.3)$ than to area change $(80 \%, R=1.1)$. State's 


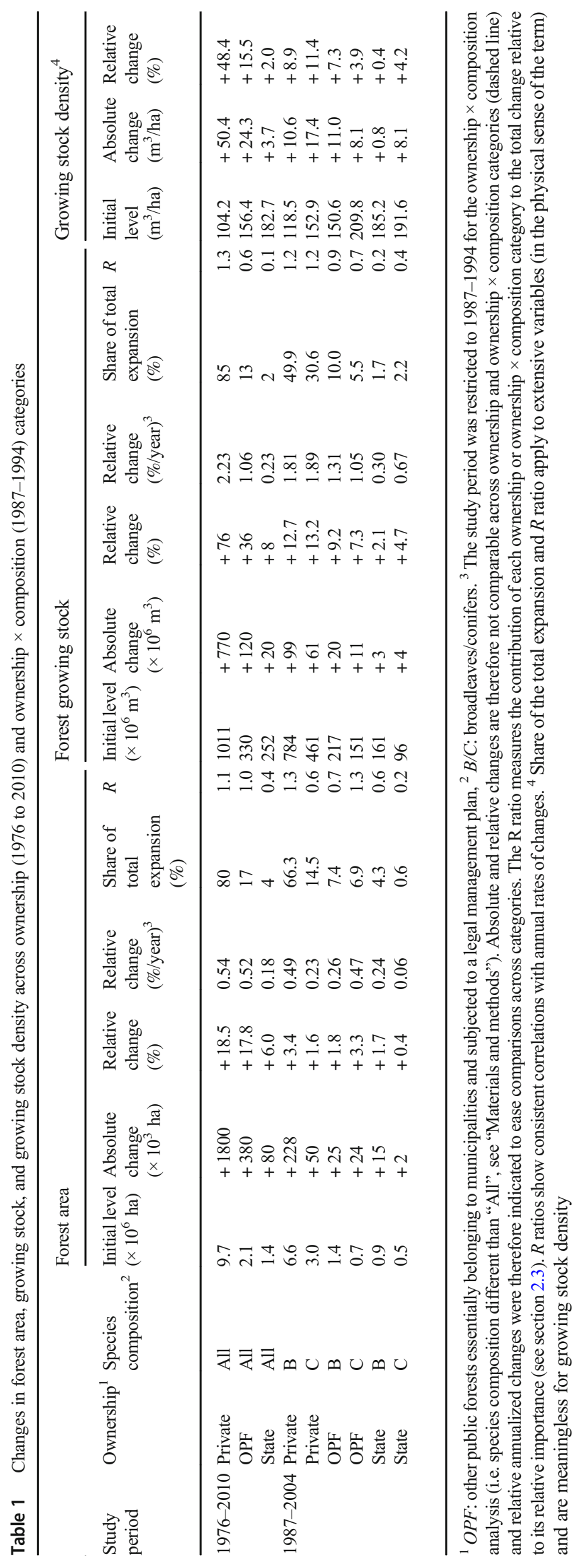

INRAC פ Springer 
forests showed relative changes in area and GS below $10 \%$, and $R$ ratios of 0.4 and 0.1 , respectively. This result confirmed their insignificant role in the total changes and the role of forest management in forest expansion. By contrast, private forests represented $63 \%$ of total GS in 1976, and now represent $71 \%$ of it.
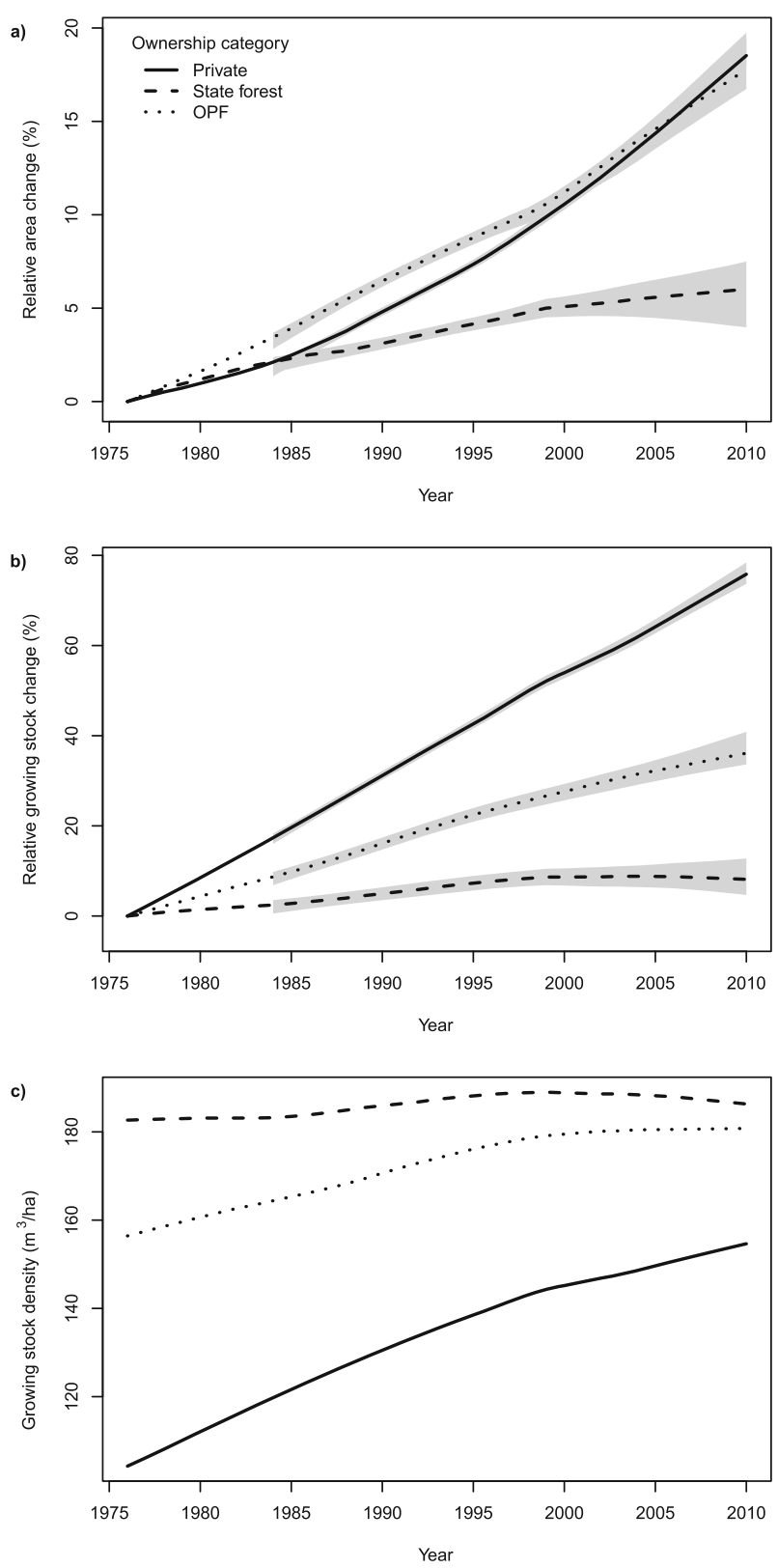

Fig. 3 Relative changes in forest area (a) and growing stock (b) and absolute changes in growing stock density (c) across ownership categories over the period 1976-2010. Relative changes are expressed as percentages of 1976 estimates. OPF refers to 'other public forests' subjected to a legal management plan. The $95 \%$ bilateral confidence intervals were established from 10,000 bootstrap samples in the distributions of sampling uncertainty in the NFI estimates and are figured in grey colour (Annex 2)

\subsubsection{Forest changes across ownership $\times$ composition strata (1987-1994)}

Private broadleaved forests formed the largest stratum (6.6 million ha) and showed a substantial areal increase of around 230,000 ha over the period $\left(p=10^{-4}\right)$, and presented the greatest relative increase $(+3.5 \%)$ and change intensity $(R=1.3)$ in area among strata (Table 1), which was also found over 2006-2014 (Annex Table 4). Only coniferous OPF exhibited a similar change intensity $(R=1.3)$ in areal expansion, however negligible in absolute terms $(+24,000$ ha; $p<0.01)$. Private broadleaved and coniferous forests also showed the greatest relative increases in GS (both greater than $10 \%$; $p<10^{-3}$ ) and intensities of change greater than the unity $(R=1.2)$, observed only in these two strata. Private broadleaved forests thus formed the dominating stratum in the observed GS changes. Over 2006-2014, these two strata also showed the greatest annual rates of changes for both area and GS (Annex Table 4).

In 1987 (beginning of the compositional study period), GSD was greatest in coniferous OPF $\left(209.8 \mathrm{~m}^{3} / \mathrm{ha}\right)$ and lowest in broadleaved private forests $\left(118.5 \mathrm{~m}^{3} / \mathrm{ha}\right)$. The smallest increases in GSD were found in State's forests, particularly in broadleaved forests that were found stationary $\left(+0.8 \mathrm{~m}^{3} / \mathrm{ha}\right.$; $p=0.7)$. The greatest increases were found in private forests (especially in coniferous forests; $+17.4 \mathrm{~m}^{3} /$ ha in coniferous and $+10.6 \mathrm{~m}^{3} /$ ha in broadleaved forests; $p<10^{-3}$ in both cases $)$ and broadleaved OPF $\left(+11.0 \mathrm{~m}^{3} / \mathrm{ha} ; p<10^{-3}\right.$; Table 1$)$.

Noticeably, all private forests represented more than $80 \%$ of the total changes in both area and GS (Table 1). The contribution of private broadleaved forests was greater for area (66\% of the areal expansion) than for GS changes (50\% of volume expansion). By contrast, the contribution of coniferous forests to areal increases was minor $(15 \%, R=0.6$, against $R=1.3$ in broadleaved forests), indicating that private coniferous (resp. broadleaved) forests contributed less (resp. more) to forest area than volume expansion, and that conifer forests were thus older than broadleaved forests. This inversion of greater intensity of change in forest area (broadleaved forests) vs GS (conifer forests) was also confirmed over 2006-2014, indicating a persisting pattern over 20 years (Annex Table 4).

\subsection{Effects of forest area and volume attributes on GS changes (objective 2)}

Variation in GS changes accounted for by the models ranged between $8 \%$ and $71 \%$, depending on the stratum under study (Table 2). In general, model goodness-of-fit increased with the finer partitioning of forests (none, ownership, ownership $\times$ composition), indicating both a practical need to partition country's forests in an attempt to decipher their GS dynamic, and the efficiency of successive partitioning factors under study for isolating strata of increasing dynamic homogeneity. 
Table 2 Summary statistics of the regression models of changes in the growing stock against forest attributes across forest ownership and composition strata. Spatial dau units formed the observations of these models. The timespan indicates the year of the first available inventory (in parentheses), the year when $80 \%$ of dau were available, and the year of the last inventory (for which all dau were available). $G S_{i}$ : initial growing stock, $G S D_{i}$ : initial mean growing stock density, $\Delta S_{-1}$ : forest area increase over the previous between-inventory period. Effects of the decreases in forest area concomitant to the studied BIP $(\Delta \mathrm{S})$ are not presented (as the variable was included as a controlled effect) but the effects were non-significant (for M1 and M2) or positive (for the other models). Semi-partial $r^{2}: r^{2}$ variation between the corresponding model and that where the predictor is dropped out. RSE: residual standard error. Test of significance: $p<0.05: *, p<0.01: * *, p<0.001: * * *$. OPF refers to 'other public forests', essentially belonging to municipalities, and subjected to a legal management plan. Relationships between total GS change (M1) and GS change in private broadleaved forests (M5) and their predictors are presented in Annex Fig. 7 and Annex Fig. 8.

\begin{tabular}{|c|c|c|c|c|c|c|c|c|}
\hline Model & Partition & & $\begin{array}{l}\text { Timespan of studied } \\
\text { between-inventory periods }\end{array}$ & $R^{2}$ & $\begin{array}{l}\mathrm{GS}_{\mathrm{i}}(\text { coefficient } \\
\text { sign) semi-partial } r^{2}\end{array}$ & $\begin{array}{l}\mathrm{GSD}_{\mathrm{i}} \text { (coefficient } \\
\text { sign) semi-partial } r^{2}\end{array}$ & $\begin{array}{l}\Delta \mathrm{S}_{-1} \text { (coefficient } \\
\text { sign) semi-partial } r^{2}\end{array}$ & $\operatorname{RSE}\left(\mathrm{m}^{3}\right)$ \\
\hline & Ownership & Composition & & & & & & \\
\hline M1 & None & - & (1961)-1976-2010 & 0.35 & $(+) * * * 0.18$ & $(-)^{* *} 0.03$ & $(+)^{*} 0.00$ & 593 \\
\hline M2 & Private forests & - & & 0.55 & $(+)^{* * *} 0.37$ & $(-)^{* *} 0.02$ & $(+)^{*} 0.00$ & 500 \\
\hline M3 & OPF & - & & 0.26 & $(+)^{* * * *} 0.11$ & & $(+)^{* * *} 0.00$ & 374 \\
\hline M4 & State's forests & - & & 0.08 & & & $(+)^{* * *} 0.03$ & 287 \\
\hline M5 & Private forests & Broadleaved & (1971)-1987-2010 & 0.54 & $(+)^{* * * *} 0.39$ & $(-)^{*} 0.03$ & & 457 \\
\hline M6 & Private forests & Coniferous & & 0.71 & $(+)^{* * *} 0.16$ & $(-)^{*} 0.00$ & & 522 \\
\hline M7 & OPF & Broadleaved & & 0.35 & $(+)^{* *} 0.00$ & & $(+)^{* * *} 0.09$ & 398 \\
\hline M8 & OPF & Coniferous & & 0.36 & $(+) * 0.03$ & & $(+)^{* * *} 0.04$ & 370 \\
\hline M9 & State's forests & Broadleaved & & 0.21 & & & $(+)^{* * *} 0.05$ & 227 \\
\hline M10 & State's forests & Coniferous & & 0.33 & & & $(+)^{* * *} 0.21$ & 301 \\
\hline
\end{tabular}

Goodness-of-fit was also greater in strata showing expansions of greater magnitude (see Table 1).

The effect of the initial GS was systematically positive when detected, but was not found in some strata, including State's forests (models M4, M9, and M10) which showed small changes in the growing stock (Table 1). The positive effect of previous temporal increases in the forested area was found in all but private ownership $\times$ composition strata (models M5 to M10), evidencing the delayed effect of increased forest area on growing stock change, even over restricted time periods. In OPF broadleaved (M7) and State's coniferous (M10, Table 2) forests, this effect had a substantial intensity, accounting for 10 to $20 \%$ of GS changes. A negative effect of the GSD, assumed to represent the competitiondriven slowing of growing stock increases, was found in strata exhibiting great GS increases (countrywide forests, M1; private forests, M2; and private $\times$ broadleaved forests, M5; Table 2). This effect however had a much lower intensity on GS changes than the initial GS, as indicated by its partial $r^{2}$ and significance (Table 2, Fig. 4). To clarify this outcome and evaluate whether the magnitude and significance of negative effects of GSD may have changed over
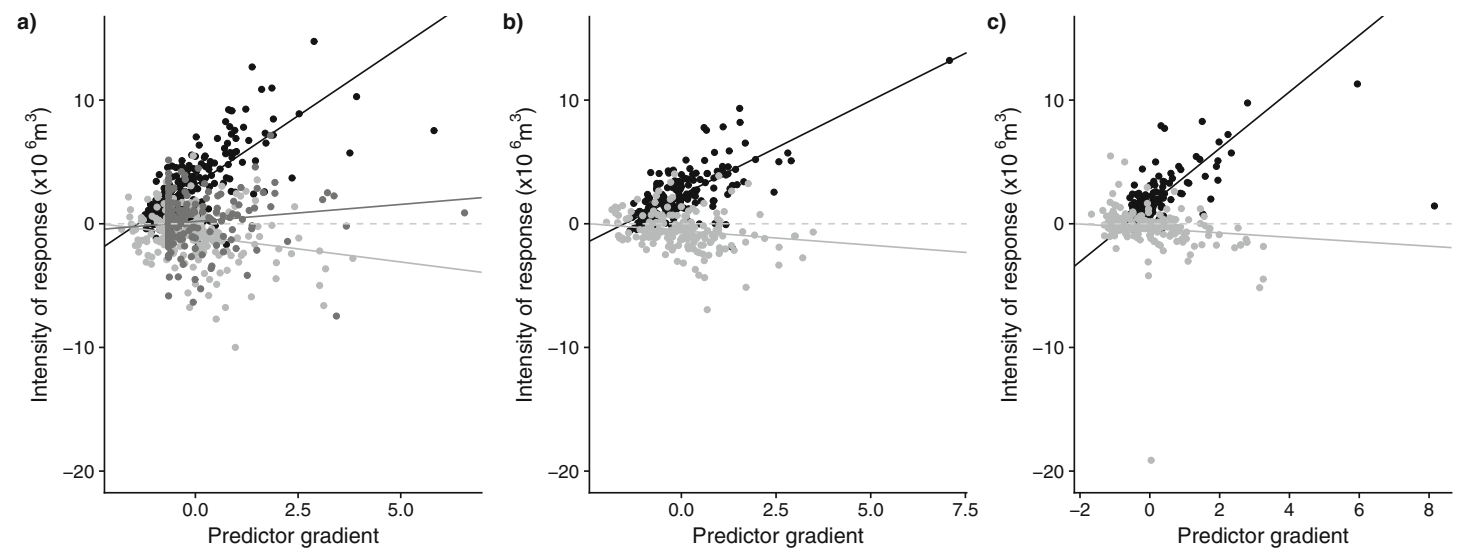

Fig. 4 Relative magnitude of the effects of initial growing stock (+, black), recent increase in area (+, grey) and initial growing stock density (-, light grey) on growing stock changes in private forests (a), private broadleaved forests (b), and private coniferous forests (c). The

range of the different predictors was standardized to allow comparison of the effects' magnitude (predictor gradient in $[-2,2]$ at a $95 \%$ confidence level) 
time, we fitted models M2 (private forests) and M5 (private broadleaved forests) on two data subsets including the first or the last BIP periods available, respectively. Of note, in M5, the intensity of the GSD effect was greater in the latter period (semi-partial $r^{2}$ of 0.06; Annex Table 7) than in the former period (semi-partial $r^{2}$ of 0.02) and turned significant, suggesting that the density-dependence (GSD) of changes in GS may have arisen later in the period. By contrast, however, the contrary was found for private forests as a whole (M2, Annex Table 7).

While fitted on more restricted datasets, models including forest areal increases over the two previous BIP showed a greater goodness-of-fit and explained $14-81 \%$ of variation in GS changes. Previous areal increases in $\Delta \mathrm{S}_{-2}$ were significant in most models (Annex Table 6) and showed evidence of both the delayed and inertial contribution of areal change to GS changes, in support to spatial patterns of forest changes (Fig. 2), but also the effectiveness of this effect over a short time period (around one to two decades).

\section{Discussion}

\subsection{Patterns and magnitude of forest changes in area and growing stock (objective 1)}

\subsubsection{Country-scale forest changes}

At a country scale, GS increased by $906 \mathrm{hm}^{3}$ between 1976 and 2010 (Fig. 1). These wood resources accumulated over 35 years are quantitatively equivalent to the current total GS of European countries such as Spain, Norway, or Turkey (944, 1033, and $1032 \mathrm{hm}^{3}$, respectively; Forest Europe 2015), and stress the intensity of GS accumulation in France. The latter represents an opportunity for the current European bio-economy strategy (European Commission 2015), and further constitutes an additional and timely carbon sink, making its future dynamic a crucial issue.

Rates of changes were three-fold greater in GS than in forest area (Fig. 1) and highlighted the strength of current forest densification in a context where concomitant forest areal increases were already intense. As a result, GSD increased by $34 \%$ on average, in accordance with increases in the biomass carbon stock per hectare observed in previous studies (Ciais et al. 2008; Dupouey et al. 2010). Altogether, these results confirm that French forests are at an already advanced stage of the forest transition, arising from ancient areal extension processes (Cinotti 1996), with a turning point situated in the first half of the nineteenth century (Mather et al. 1999). As an example of an earlier stage of forest transition, forests in Vietnam recently presented an increase in area, along with a decrease in GSD (FAO 2015), consistent with the phase where increases in the forest area contribute in a first step to a decrease in average GSD (Kauppi et al. 2006).

Forest transition has initially been defined and explored at a country scale, with a warning that it may not be identified over restricted geographic domains (Mather 1992; Mather et al. 1999). Our results clearly demonstrate the large spatial heterogeneity in these changes within a country (Fig. 2), in line with observations carried out in other countries (Switzerland in Loran et al. 2016; Norway in Fjellstad and Dramstad 1999; USA with a longitudinal EW gradient in Kauppi et al. 2006). In addition, spatial patterns in areal and GS expansion considerably differed in our study area (Fig. 2). The greater accuracy of GS change regression models with partitioning of forests also supports the need to acknowledge such heterogeneities. In this respect, the mechanisms through which a spatially heterogeneous and temporally non-stationary areal expansion leads to smooth forest expansion trajectories at a higher scale (Fig, 1, see also Marey-Pérez and Rodriguez-Vicente 2008) remains unclear and would require investigations on the role of spatial scaling in the appraisal of forest transition processes.

These spatial patterns also fit historical facts well. Southern Mediterranean France has been subjected to significant farmland abandonment (Chakir and Madignier 2006). The reported areal expansion in this area of the French territory footprints this process (Fig. 2a). Moreover, forest management intensity in these forests is often low, due to their lower productivity and accessibility, and to fragmentation of former agricultural estates (de Galbert et al. 2015), contributing to an increase in GS. Between 1946 and 1999 the FFN plantation program resulted in an increase in forest area of $c a 800,000$ ha (Dodane 2009). This afforestation was not homogeneous over the whole country and some targeted areas were privileged (including the Central Mountain range; Dodane 2009). This process accounts for the extension of the area and increase in GS observed in the central mountain range and central France (Fig. 2a and b). Between 1910 and 1970, area extension was greater in the Central Mountain range (Normandin 1979; Denardou et al. 2017) than in the rest of the country. Densification of these new forests was subsequently observed, as illustrated in Fig. 2c. Decreases in the GS recorded in three dau (Fig. 2b) were related to severe windstorms in 1999 and 2009, which caused $176 \mathrm{hm}^{3}$ (Ministère de 
l'agriculture 2005) and $43 \mathrm{hm}^{3}$ (IFN 2009) of windfall tree volume, respectively, with greater impacts in the South-West and the North-East.

\subsubsection{Forest changes across ownership strata}

Forest changes also exhibited heterogeneity among ownership categories. Forest area and GS increased by far greater in private lands (Table 1) than in any other ownership category. This increase, widespread over the territory (Annex Fig. 6) did not depend on private ownership distribution, of lowest prevalence in half-Eastern France (Pulla et al. 2013), i.e. in a context of generally more intensive management. This magnitude extrapolates to a singular doubling in these forests' GS in less than 50 years (42.5 years). The rate of change of area in OPF was similar to that observed in private forests. Whereas highest increases found in private forests relate to an unconstrained forest colonization dynamic, the inclusion of new OPFs expanding on public lands also depends on legal recognition processes (enforcement of public management plans). While these are able to generate some temporal delay in the increase of OPF area, no related official figures or analyses are available to date. Also, the dynamic of State's forests appears to be even more constrained, yet not null (Table 1). In the absence of an explicit extension policy over recent decades, these restricted changes suggest that natural expansion operates in once non-productive areas of these State's forests (18\% in the statistics of 1892, Cinotti 1996). This trend in the extension of private forests has also been observed between 1910 and 1970 (Normandin 1979), with fourfifths of the total expansion located in private forests, a proportion thus similar to that observed between 1976 and 2010. This major increase in the area of private forests (Table 1; Fig. 3) is related to agricultural land abandonment and subsequent afforestation, either natural or by plantations (Chakir and Madignier 2006), a long-term process observed throughout Europe over decades (Lasanta et al. 2017; Keenleyside and Tucker 2010). Moreover, private broadleaved forests represented most of the absolute forest expansion (two-thirds of the area, $50 \%$ of GS, Table 1). Whereas the R ratio of GS changes was identical in coniferous and broadleaved forests $(R=$ 1.2 ), it was twice greater for the areal expansion in broadleaved than in coniferous forests $(R=1.3$ and 0.6 , respectively), a finding that admits two interpretations: (i) GS dynamics in broadleaved forests remains slower than in coniferous forests due to the dominance of natural afforestation by pioneer species in less fertile zones (e.g. ancient grasslands), versus active afforestation with coniferous tree species, in more favourable ecological conditions (e.g. ancient crop fields), (ii) areal extension in coniferous forests is more ancient than in broadleaved forests (the FFN plantation program, which has essentially favoured coniferous species, has produced its main effect between 1950 and 1970; Dodane 2009), and/ or currently less intense than it previously was, hence GS increases in broadleaved forests may increase in the future. Accordingly, temporal trends in the rates of change in GS (data not presented) showed a slowing of GS changes in private coniferous forests, not found in private broadleaved ones. To progress further in the understanding of these differences, joint analyses of forest expansion and dated maps of forest occupation (Abadie et al. 2017), together with forest soil fertility maps (Coudun and Gégout 2005) are needed.

State's forests contributed very little to GS changes and thus did not form a primary target of current challenges including the fostering of wood resource use and $\mathrm{C}$ sequestration. This noticeably questions the representativeness of public forest management as an effective paradigm for guiding forestry practices in general (Kennedy et al. 1998).

In addition to former areal expansion, forest management has also caused this difference in GS changes, as suggested by GSD indicators (Table 1, Fig. 3). First, GSD was lowest in private forests at the beginning of the study period $\left(100 \mathrm{~m}^{3} / \mathrm{ha}\right)$, and much lower than in State's forests $\left(180 \mathrm{~m}^{3} / \mathrm{ha}\right)$, in which the conversion of broadleaved coppice stands into high forests has been fostered for long (Hüffel 1927). In contrast, energyoriented coppice and coppice-with-standard forest production systems have remained more frequent in private forests (Hüffel 1927). Accordingly, current NFI statistics (2006-2012) indicate a prevalence of $43 \%$ for these lowstocked systems in private forests, against $31 \%$ in OPF and only $20 \%$ in State's forests. That GSD in private forests also showed the fastest increase over the study period (+50\%), implies that harvest in these low-stocked forests has been restricted, by contrast to State's forests where forest management has been more intense for long. Accordingly, inventory statistics for the periods 2005 2009 and 2014-2018 indicate annual felling rates of volume of $2.25 \%$ in State's forests, against $1.7 \%$ in private forests (and $1.75 \%$ then $1.5 \%$ in OPF), with differences in GSD keeping on narrowing (Fig. 3). Low-intensity harvesting is more likely to have occurred in returning forests over private abandoned agricultural areas due to their early developmental stage, and to a deficit of strategic planning given the physical and economic constraints (slope, poor fertility, low accessibility, Levers et al. 2014) of these forests. Differences in the GSD across ownership categories thus tend to narrow (Fig. 3) over time. 


\subsubsection{Forest changes across ownership and composition strata}

Rates and $\mathrm{R}$ ratios of GS changes in coniferous and broadleaved private forests (Table 1) were comparable. Statistics on forest structure indicate that coppice and coppice-with-standard production systems actually dominate private broadleaved forests $(60 \%$ of the area over 2006-2012), yet represent only $10 \%$ of forests dominated by conifer species. This ratio likely accounts for the moderate level of growing stock of private broadleaved forests $\left(118.5 \mathrm{~m}^{3} / \mathrm{ha}\right.$ for broadleaved forests) as compared with coniferous forests $\left(152.9 \mathrm{~m}^{3} / \mathrm{ha}\right)$, as mean GSD of coppice-with-standard and coppice forests are much lower than mean GSD of high forests (147 and $66 \mathrm{~m}^{3} /$ ha for coppice-with-standard and coppice forests, against $201 \mathrm{~m}^{3} /$ ha for high forests). Thus, natural ageing of these broadleaved production systems might counterbalance GS expansion resulting from active coniferous afforestation programs. A full understanding of causal forest management processes of this expansion requires mandatory explorations of diameter-structured budgets of GS and growth/harvest flux balance across ownership categories, making more global analyses insufficient (Le Noë et al. 2020). Such analyses at hand with NFI data are underway. Also, analyses accounting for ownership heterogeneity among private forests are needed, but currently lack comprehensive spatialized information on forest management plans, whose elaboration is underway in France.

\subsection{Effects of forest attributes on GS changes (objective 2)}

Models of GS change across between-inventory periods of the different forest strata confirmed the hypotheses initially considered (Table 2). First, initial GS had a positive effect on GS change, except for strata of stable GS (Table 1), interpreted as a capital-production relationship (Berryman 1992). Second, increases in forest area over the previous between-inventory periods (BIP) also had positive effects on GS changes, except in broadleaved and coniferous private forests, and reflected the delayed development of the growing stock in the associated strata. The absence of this effect in private forests was not expected in this stratum where areal increases were observed (see 3.1.2, Table 1). However, this effect was significant in models fitted on the whole private strata (model M2), despite being of very moderate intensity. This result demonstrates the limited ability to interpret such demographic process models when fitted on large strata. The existence of this effect in public forests (models M3 and M4) might reflect the following processes: (i) more intense management leading to the faster growth of new forests, or (ii) changes in the ownership status of existing forests (essentially private forests moving to $\mathrm{OPF}$ ), also able to reduce this effect in the private forests. While this delayed effect of areal extension certainly contributes to GS over periods exceeding the typical study-BIP (12 years on average), the definition of forests applied by the NFI before 2005 tended to identify new forest areas as soon as growing stock was close to detection. This approach contrasted with the more recent international definition of forests applied since 2005 (FAO 2004). Furthermore, models including the two previous between-inventory periods showed a significant effect of both periods. This confirmed the longer-term effect of previous area increases on GS changes. Third, the negative effect of growing stock density on GS changes can reflect density-dependence processes (competition) able to slower GS increases. A negative effect of GSD (Table 2) was identified at country scale, as well as in strata showing the greatest increases in the growing stock (Table 1), namely private and private broadleaved forests. Model fits on subsets defined by the first and final study periods available in the whole dataset revealed a stronger intensity of this effect of GSD over the most recent period in private forests (see 3.2). However, the opposite was found in private broadleaved forests. This result supports the recent emergence of a competition-driven footprint on increases in growing stock in a part of the French forests. Nevertheless, among all predictor variables, the initial GS had the greatest intensity on variation in GS (Table 2; Fig. 4), suggesting that GS increase is far from levelling down. As an additional control, we computed the correlation between initial GSD of the study period and R ratios at dau scale (without any partitioning of forests). Accordingly, we found a negative correlation $(-0.6$; $p<10^{-8}$ ) between these quantities, suggesting a lower intensity of change in dau of greater GSD. A graphical analysis (Annex Fig. 9) however revealed that the magnitude of this correlation relied on a few spatial units (when the 10 dau with the highest GSD were removed, the correlation dropped down to $-0.4 ; p<10^{-4}$ ). Thus, early signs of density-dependence in GS changes (Table 2) can be found in extreme situations, but are seemingly not sufficient to reduce current GS expansion.

In private forests, $55 \%$ of GS variation were accounted for by models, versus $26 \%$ and $8 \%$ for OPF and State's forests, respectively, showing a clear relationship between model accuracy and the magnitude of expansion. Furthermore, models explained $71 \%$ of the variation in the GS of coniferous private forests, but only $54 \%$ of that in broadleaved private forests. In France, a large fraction of coniferous private forests originated from plantations set up in the mid-twentieth century and are quite homogeneous and synchronous in terms of demographic processes. By contrast in broadleaved forests, more natural processes, 
occurring over a longer-term and resulting from abandonment likely contribute to heterogeneity among inventory periods under study, making associated statistical effects more difficult to capture.

Some facts now need to be gathered: (i) the growing stock of French forest has been steadily increasing over the last decades, (ii) the area of French forests has also increased by $17 \%$ over a 40 -year study period (Fig. 1), and did not show any recent slowing down, (iii) past areal increases had a positive effect on later GS changes, (iv) average GSD remains lower than that of many other neighbour European countries $\left(168.3 \mathrm{~m}^{3} / \mathrm{ha}\right.$ compared with, e.g. $320.8 \mathrm{~m}^{3} /$ ha in Germany; Forest Europe 2015). Altogether, these facts support the idea that such GS increase is prone to last at least in the next set of decades, and as such largely out of inclusion in the standard time horizon of forest policies. Persisting abandonment of marginal agricultural lands in Europe (Verburg et al. 2010), moderate harvest rates (Forest Europe 2015), and growing reluctance to harvest forests in view of conservation (Hall et al. 2012) or environmental issues (Luyssaert et al. 2008; Vanhala et al. 2013) should favour this forest expansion. Conversely, ongoing climate change and its adverse potential consequences on forests may also severely counterbalance this dynamic in the future, including major disturbances such as extreme (Ciais et al. 2005) and repeated drought years such as the recent sequence 2018-2020, storms (Gregow et al. 2017) and subsequent insect outbreaks (e.g. Rouault et al. 2006), whose attribution to global change is increasing (Cornwall 2016). However, the average annual productivity of French forests over the more recent years 2014-2018 after the study period was found very stable $\left(5.66 \mathrm{~m}^{3} / \mathrm{ha} /\right.$ year in 2018 against $5.77 \mathrm{~m}^{3} /$ ha/year in 2014) and proved not significant. Should climate threat materialize as anticipated, forest growing stock in the twenty-first century would hence situate at the unprecedented crossroad of major and adverse drivers, making evolution of decision frameworks crucial (Millar et al. 2007). In view of GS stock trajectories, concomitant forest soil inventories aimed at quantifying the associated $\mathrm{C}$ stock also form an urgent need (Prechtel et al. 2009). Also, whether forests would better mitigate climate warming through $\mathrm{C}$ stocking or fossil fuel substitution needs clarification (McKechnie et al. 2011; Vanhala et al. 2013), as it has adverse consequences on the forest growing stock.

\section{Conclusions}

- Relative changes in the French forests' growing stock has been three-fold greater than in area over a 40-year period and stresses the prevalence of forest densification over its areal extension. The fastest changes in private forests are supported by the absence of legally-binding management plans, low initial growing stock density associated with short-rotation forest systems, confirming the role of extensive forest management and abandonment in this evolution.

- GS and GSD increases demonstrate the already advanced stage of the forest transition in France, initiated in the early nineteenth century. Yet, both (i) strong positive dependence of GS expansion onto the initial GS and (ii) low average levels of GSD with respect to those of several other European countries like, e.g. Germany, Austria or Romania ( $>250-300 \mathrm{~m}^{3} / \mathrm{ha}$ ), and only discrete/recent signs of GSD-driven limitation indicate that GS increases will be maintained in future decades, making these forests a persisting aerial carbon sink. The magnitude of these changes and the still moderate afforestation rate (one-third of the territory) make the asymptotic time horizon of this expansion distant. However, increasing climate threat on forests may thwart this trend, with uncertain outcome.

- The significance of investigations at scales finer than country-scale is demonstrated, with important heterogeneities evidenced with respect to space, ownership, and composition attributes. Spatial analyses of area and GS allowed distinguishing phases of forest development, e.g. between private broadleaved and coniferous forests. The primary role of private broadleaved forests in GS expansion was evidenced, and supports the idea of largely natural and uncontrolled processes, out of forest policy frameworks.

- Due to intensified survey of forests by NFI programs and the genericity of methods used, such researches may be replicated in other countries, and deliver invaluable information on current forest dynamics at broader and up to a continental scale. It is especially relevant in temporary-plot sampling designs where no plot-wise approaches can be implemented. Moreover, annual forest inventories could support real-time monitoring of growing stock or carbon budgets, crucial in a rapidly worsening climatic context.

Acknowledgements The authors thank the French forest inventory service of IGN and François Morneau for providing important contributions and allowing us to use the first inventories. They also wish to express their deepest thanks to the three anonymous reviewers of this manuscript for improving clarity, and Dr. Olivier Bouriaud for stimulating discussions. This work is dedicated to Jean-Christophe Hervé, founder of the French Laboratory of Forest Inventory (LIF), who initiated this work on forest expansion and who suddenly passed away on April 16, 2017.

Funding This work was financially supported by the French Environment and Energy Management Agency (ADEME), the Lorraine region and the Labex ARBRE (ANR 11-LABX-0002).

Data availability The datasets generated during and/or analysed during the current study are available from the corresponding author on reasonable request. Data regarding the new forest inventory method 2005-2019 are available publicly at https://inventaire-forestier.ign.fr/. 


\section{Compliance with ethical standards}

Conflict of interest The authors declare that they have no conflict of interest.

\section{Annexes}

\section{Annex 1. Forest definitions and data available}

The French forest inventory was initiated in 1961 and conducted by "department" administrative units (dau) at a pace of about one dau every 12 years (first method of inventory, M1; see Table below, Robert et al. 2010, 207-221 in Tomppo et al. (2010) National Forest Inventories, Pathways for common reporting, Springer, 611 pp.). From 2005 onwards, the inventory has turned systematic continuous, with the whole afforested area being inventoried every year at a 1:10th intensity (second method or M2; Hervé 2016). In both methods, plots were temporary.

Area Forest state is defined by minimum area, minimum width, tree cover, and potential tree height, in accordance with the principles of the international definition for forests (FAO 2004, Global FRA update 2005, terms and definitions), adopted in method M2. In both inventory methods, forest definition was very close, and was defined as a minimum surface of 0.5 ha and a minimum tree cover of $10 \%$. Criteria for minimum width and potential tree height varied between methods M1 and M2, making method M2 more sensitive than M1 to natural afforestation. In method M1 (resp. M2), the surface should have a minimum width of $25 \mathrm{~m}$ (resp. $20 \mathrm{~m}$ ) with trees of a potential minimum height of $7 \mathrm{~m}$ (resp. $5 \mathrm{~m}$ ). As an alternative to the tree cover criterion, a minimum 500 stems/ha were targeted in method M1 in plots with trees with a diameter at breast height (dbh) smaller than $7.5 \mathrm{~cm}$. The greater sensitivity of forest definition in method M2 than in M1 has generated a noticeable positive shift by around 300,000 ha in the total afforested area. This shift was taken into account into how analyses were designed. In the method M1, forests were divided into three categories: (1) "forests" correspond to an area above 4 ha and a width greater than $25 \mathrm{~m},(2)$ "woodlands" have an area between 0.5 ha and 4 ha and a width greater than $25 \mathrm{~m}$, (3)" small woodlands" have an area between 0.05 and 0.5 ha and a width above $15 \mathrm{~m}$. In the case where the width is between $15 \mathrm{~m}$ and $25 \mathrm{~m}$, the forest has no area limit. The second category was merged with the first one in method M1 to make forest statistics comparable with those of method M2. The latter category could not be separated from forests and woodlands in M1 but it was evaluated to constitute only $1 \%$ of the total area and GS.

Growing stock Within plots belonging to surfaces classified as forests, the volume of the GS is defined as the sum of stem volumes from the ground up to a minimal cross-sectional diameter of $7 \mathrm{~cm}$ for trees with a dbh greater than $7.5 \mathrm{~cm}$. This definition has remained constant throughout the study period (M1 and M2). Before 2005 (M1), tree volume was estimated using means computed over very small forest domains, defined at a dau scale, and resulting from a fine-resolution stratification of forest based on several attributes. After 2005, the estimation was based on countrywide volume eqs. (M2). Temporal continuity was verified by the French NFI.

Forest composition Data for composition from the first dau inventories were not available (Table 3; Fig. 5). In the following inventories, composition was not described for plots with restricted tree cover (below 10\% before 2005 M1-, and below 15\% thereafter -M2). These forests represent $8 \%$ of the total forest productive area and $0.3 \%$ of the total GS on average over 2006-2014. Consequently, these forests were discarded from analyses involving this compositional attribute.

Table 3 Properties of the national forest inventory data used in the study. dau: department administrative unit. Since the inventory in method M1 was asynchronous between $\mathrm{dau}$, periods in this method are overlapping

\begin{tabular}{|c|c|c|c|}
\hline \multirow[b]{2}{*}{ Period } & \multicolumn{2}{|c|}{ First method of inventory (M1) } & \multirow{2}{*}{$\begin{array}{l}\text { Second method of inventory (M2) } \\
\text { 2005-2014 }\end{array}$} \\
\hline & 1961-1979 & 1976-2004 & \\
\hline Spatial sampling scale & \multicolumn{2}{|c|}{ Department administrative unit (dau) } & National \\
\hline Time interval between two inventories & \multicolumn{2}{|c|}{12 years on average } & Annual \\
\hline Information on forest composition & No & Yes & Yes \\
\hline Number of $d a u$ and inventories & $\begin{array}{l}74 d a u \times 1 \text { inventory } \\
5 d a u \times 2 \text { inventories }\end{array}$ & $\begin{array}{l}1 \text { dau } \times 1 \text { inventory } \\
69 \text { dau } \times 2 \text { inventories } \\
20 \text { dau } \times 3 \text { inventories }\end{array}$ & All forests every year \\
\hline
\end{tabular}




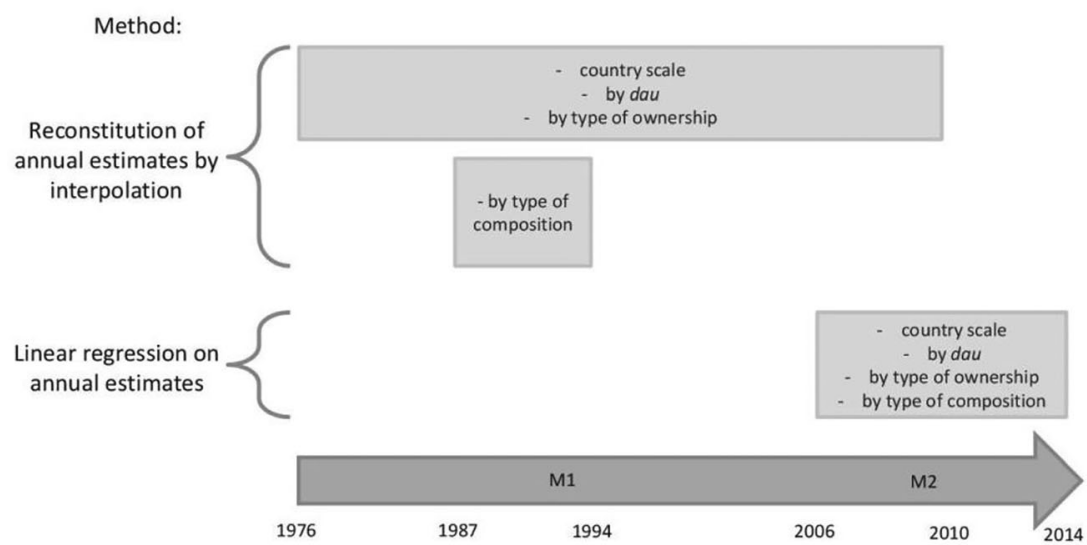

Fig. 5 Study periods, methods of estimation of temporal trends and stratification factors for the different objectives of the study. Analyses at country scale and across ownership categories formed the longest period, 1976-2010. Analysis across composition categories were restricted to 1987-1994, and 2006-2014, both because compositional data were not

Inference In the French NFI, the growing stock is obtained by two-phase sampling, where the first phase is used to estimate strata area, and the second phase for estimating the mean growing stock in the strata (Robert et al. 2010 in Tomppo et al. 2010, Springer). Total growing stock is the sum over the strata. Per area estimations are consequently based on the "ratio of means" approach that is, by dividing volume estimates for the domain (department) by the forest area estimated in the domain (as other NFIs, ex. FIA Bechtold and Patterson 2005). Thus, the interpolated estimations were performed in a similar manner. Ratio of means are widely preferred to other approaches such as the mean of ratio for its robustness (Zarnoch et Bechtold, 2000; Williams 2001). It is probable however that the difference in the estimations and the errors would be small at this spatial scale.

Bechtold, W. A., \& Patterson, P. L. (2005). The enhanced forest inventory and analysis program-national sampling design and estimation procedures. Gen. Tech. Rep. SRS-80. Asheville, NC: US Department of Agriculture, Forest Service, Southern Research Station. 85 p., 80 .

Williams, M. S. (2001). Comparison of estimation techniques for a forest inventory in which double sampling for stratification is used. Forest science, 47(4), 563-576.

Zarnoch, S. J., \& Bechtold, W. A. (2000). Estimating mapped-plot forest attributes with ratios of means. Canadian Journal of Forest Research, 30(5), 688-697.

\section{Annex 2. Bootstrap estimation of confidence intervals for forest chronologies}

For each dau-based forest inventory, an error margin for area, GS and GSD is provided in NFI statistics, corresponding to the sampling error of the inventory. To estimate confidence intervals for area and GS for all years of the study period at the country level, we used a bootstrap resampling approach, available at the origin of the study period and were not homogeneous between methods M1 and M2. Since 2005, the forest inventory program has turned continuous, and temporal trends can be evaluated through regression analysis

implemented in several steps. Step1. For each dau, each year of inventory and each forest attribute (area or growing stock), 10,000 samples were generated using a Gaussian distribution, with the mean and variance resulting from inventory estimators. Step 2. From these samples, 10,000 random chronologies were built for each of the 90 dau covering the territory under study. Linear interpolation was implemented to provide 10,000 annual dau chronologies. Step 3. For each year, the $10,000 \times 90$ interpolated chronologies were summed over the whole country, providing 10,000 country-scale chronologies. Step 4 . For each year, the quantiles at 2.5 and $97.5 \%$ levels of these 10,000 annual chronologies were picked out, and used to build the confidence interval conditional on calendar year. Since sampling errors from the oldest forest inventories were not available, the global margin of error could only be calculated starting from 1984, where $80 \%$ of the dau estimates had a margin of error.

\section{Annex 3}

Table 4 Relative changes in area and GS over the recent period 2006 2014 for some significant ownership and ownership $\times$ composition strata

$\begin{array}{llll}\text { Forest area } & \begin{array}{l}\text { Forest GS } \\$\cline { 1 - 1 } $\begin{array}{l}\text { Relative annual } \\ \text { rate of change }(\%)\end{array}\end{array} & \begin{array}{l}\text { Relative annual rate } \\ \text { of change }(\%)\end{array}\end{array}$

\begin{tabular}{lllll}
\hline Private forests & 1.07 & 1.3 & 2.17 & 1.2 \\
OPF & 0.04 & 0.1 & 1.14 & 0.6 \\
State's forests & 0.29 & 0.4 & 1.12 & 0.6 \\
Private forests (B) & 1.52 & 0.8 & 2.26 & 0.5 \\
Private forests (C) & 0.17 & 0.2 & 1.99 & 1.0 \\
\hline
\end{tabular}




\section{Annex 4}

Table 5 Correlations between model predictors for models including areal increases over the period preceding the GS increment $\left(\Delta \mathrm{S}_{-1, \mathrm{i}}\right.$, manuscript Table 2)

\begin{tabular}{|c|c|c|c|}
\hline & Variables & $\mathrm{GSD}_{\mathrm{i}}$ & $\Delta \mathrm{S}_{-1, \mathrm{i}}$ \\
\hline \multirow[t]{2}{*}{ M1 } & $\mathrm{GS}_{\mathrm{i}}$ & \multirow[t]{2}{*}{$0.54 * * *$} & -0.06 \\
\hline & $\mathrm{GSD}_{\mathrm{i}}$ & & $-0.32 * * *$ \\
\hline \multirow[t]{2}{*}{ M2 } & $\mathrm{GS}_{\mathrm{i}}$ & \multirow[t]{2}{*}{$0.30 * * *$} & -0.00 \\
\hline & $\mathrm{GSD}_{\mathrm{i}}$ & & $-0.29 * * *$ \\
\hline \multirow[t]{2}{*}{ M3 } & $\mathrm{GS}_{\mathrm{i}}$ & \multirow[t]{2}{*}{$0.53 * * *$} & 0.10 \\
\hline & $\mathrm{GSD}_{\mathrm{i}}$ & & $-0.24 * *$ \\
\hline \multirow[t]{2}{*}{ M4 } & $\mathrm{GS}_{\mathrm{i}}$ & \multirow[t]{2}{*}{$0.40 * * *$} & -0.09 \\
\hline & $\mathrm{GSD}_{\mathrm{i}}$ & & $-0.27 * * *$ \\
\hline \multirow[t]{2}{*}{ M5 } & $\mathrm{GS}_{\mathrm{i}}$ & \multirow[t]{2}{*}{$0.29 * * *$} & $0.14 *$ \\
\hline & $\mathrm{GSD}_{\mathrm{i}}$ & & $-0.35 * * *$ \\
\hline \multirow[t]{2}{*}{ M6 } & $\mathrm{GS}_{\mathrm{i}}$ & \multirow[t]{2}{*}{$0.28 * * *$} & 0.14 \\
\hline & $\mathrm{GSD}_{\mathrm{i}}$ & & $-0.25 * * *$ \\
\hline \multirow[t]{2}{*}{ M7 } & $\mathrm{GS}_{\mathrm{i}}$ & \multirow[t]{2}{*}{$0.43 * * *$} & $0.53 * * *$ \\
\hline & $\mathrm{GSD}_{\mathrm{i}}$ & & -0.06 \\
\hline \multirow[t]{2}{*}{ M8 } & $\mathrm{GS}_{\mathrm{i}}$ & \multirow[t]{2}{*}{$0.58 * * *$} & $0.51 * * *$ \\
\hline & $\mathrm{GSD}_{\mathrm{i}}$ & & $0.18^{*}$ \\
\hline \multirow[t]{2}{*}{ M9 } & $\mathrm{GS}_{\mathrm{i}}$ & \multirow[t]{2}{*}{$0.47 * * *$} & $0.46 * * *$ \\
\hline & $\mathrm{GSD}_{\mathrm{i}}$ & & 0.14 \\
\hline \multirow[t]{2}{*}{ M10 } & $\mathrm{GS}_{\mathrm{i}}$ & \multirow[t]{2}{*}{$0.33 * * *$} & $0.45^{* * *}$ \\
\hline & $\mathrm{GSD}_{\mathrm{i}}$ & & -0.01 \\
\hline
\end{tabular}

$G S_{\mathrm{i}}$ : initial growing stock of dau unit $\mathrm{i}, G S D_{\mathrm{i}}$ : initial mean density of growing stock, $\Delta \mathrm{S}_{-1, \mathrm{i}}$ : forest area increases over the previous betweeninventory period. Test significance: $P<0.1:(*), P<0.05: *, P<0.01$ : **, $P<0.001: * * *$

\section{Annex 5}

Table 6 Summary statistics of regression models of GS change including areal changes over the two previous between-inventory periods as predictors

\begin{tabular}{|c|c|c|c|c|c|c|c|c|}
\hline Model & Partition & $\begin{array}{l}\text { Time span of studied } \\
\text { between-inventory } \\
\text { periods }\end{array}$ & $R^{2}$ & $\begin{array}{l}\mathrm{GS}_{\mathrm{i}} \\
\text { (coefficient } \\
\text { sign) partial } R^{2}\end{array}$ & $\begin{array}{l}\mathrm{GSD}_{\mathrm{i}} \\
\text { (coefficient } \\
\text { sign) partial } R^{2}\end{array}$ & $\begin{array}{l}\Delta \mathrm{S}_{-1, \mathrm{i}} \\
\text { (coefficient } \\
\text { sign) partial } R^{2}\end{array}$ & $\begin{array}{l}\Delta \mathrm{S}_{-2, \mathrm{i}} \\
\text { (coefficient } \\
\text { sign) partial } R^{2}\end{array}$ & $\begin{array}{l}\text { RSE } \\
\left(\mathrm{m}^{3}\right)\end{array}$ \\
\hline M1' & None & (1961)-1976-2010 & 0.34 & $(+) * * * 0.08$ & & $(+) * * * 0.02$ & $(+) * * * 0.05$ & 629 \\
\hline M2' & Private forests & & 0.45 & $(+) * * * 0.28$ & & $(+) * * * 0.03$ & & 578 \\
\hline M3, & OPF & & 0.16 & & $(+) * 0.00$ & $(+) * * * 0.01$ & $(+) * * * 0.01$ & 400 \\
\hline M4' & State's Forests & & 0.14 & & & $(+) * * 0.04$ & $(+) * 0.03$ & 284 \\
\hline M5 & $\begin{array}{l}\text { Private broadleaved } \\
\text { forests }\end{array}$ & (1971)-1987-2010 & 0.54 & $(+) * * * 0.35$ & $(-) * * 0.05$ & & & 492 \\
\hline M6' & Private coniferous forests & & 0.81 & $(+) * * * 0.04$ & & $(+) * 0.06$ & & 588 \\
\hline M7' & Broadleaved OPF & & 0.46 & $(-) * * * 0.04$ & $(+) * * * 0.00$ & $(+) * * 0.02$ & $(+) * * * 0.15$ & 341 \\
\hline M8 & Coniferous OPF & & 0.43 & & & $(+) * * * 0.06$ & $(+) * * * 0.06$ & 332 \\
\hline M9' & $\begin{array}{l}\text { State's broadleaved } \\
\text { forests }\end{array}$ & & 0.43 & $(-) * 0.09$ & & & $(+) * * * 0.16$ & 230 \\
\hline M10' & State's coniferous forests & & 0.34 & $(-) * 0.06$ & & $(+) * 0.04$ & $(+) * 0.10$ & 304 \\
\hline
\end{tabular}

The time span indicates the dates of the first available inventory (in parentheses), the date when $80 \%$ of dau were available and the date of the last inventory. $G S_{\mathrm{i}}$ : initial growing stock of dau unit i, $G S D_{\mathrm{i}}$ : initial mean density of growing stock, $\Delta \mathrm{S}_{-1, \mathrm{i}}$ (resp -2 ): forest area increases over first (resp. second) previous between-inventory periods. $R S E$ : residual standard error. Test significance: $P<0.1:(*), P<0.05: *, P<0.01$ : **, $P<0.001$ : ***. OPF refers to 'other public forests', essentially belonging to municipalities, and subjected to a legal management plan 


\section{Annex 6}
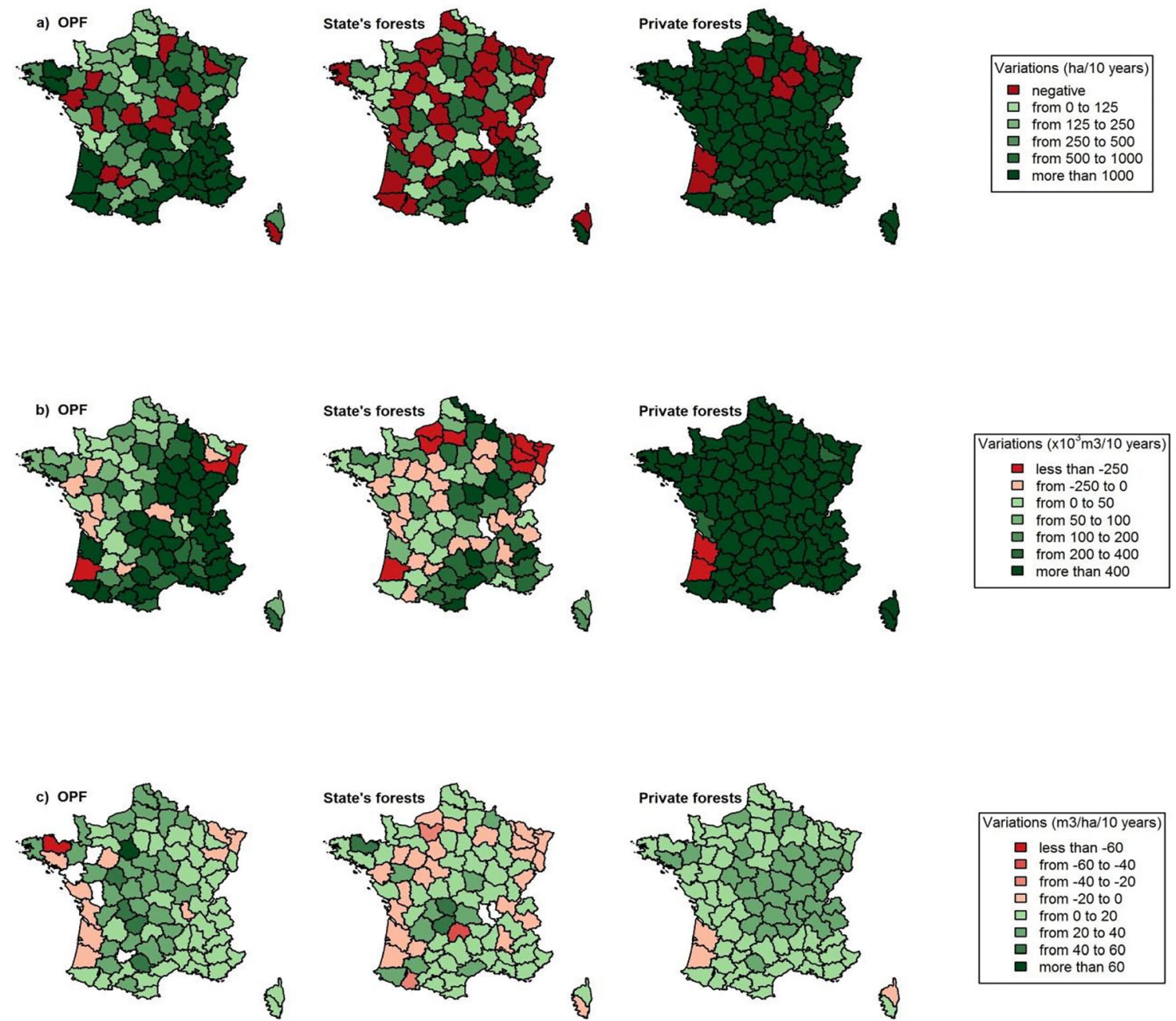

Fig. 6 Decennial changes in forest area (a), growing stock (b), and GSD (c) across ownership categories and dau administrative units over the period 1976-2010

\section{Annex 7}

Table 7 Compared effects of growing stock density (GSD) in regression models of GS changes over the first or the last between-inventory periods (BIP) available in the dataset. $P<0.1:(*), P<0.05: *, P<0.01: * *, P<0.001: * * *$

\begin{tabular}{llll}
\hline & & First period & Last period \\
\hline M2 private forests & Parameter estimate $\left(\mathrm{m}^{3} / \mathrm{ha}\right)$ & $-667 * *$ & -512 \\
& Semi-partial $r^{2}$ & 0.03 & 0.01 \\
M5 broadleaved private forests & Parameter estimate $\left(\mathrm{m}^{3} / \mathrm{ha}\right)$ & -252 & $-769^{* *}$ \\
& Semi-partial $r^{2}$ & 0.02 & 0.06 \\
\hline
\end{tabular}




\section{Annex 8}
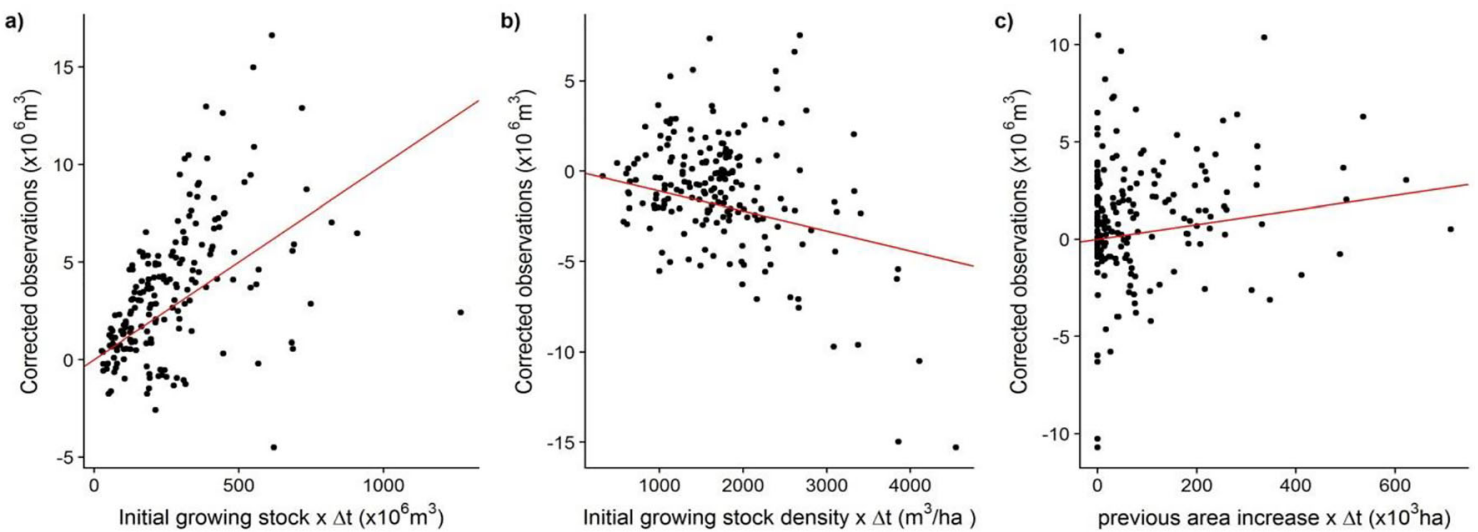

Fig. 7 Country-scale GS changes against model predictors (partial predictions, corrected for the effects of other predictors; model M1)

\section{Annex 9}

Fig. 8 GS changes in private broadleaved forests against model predictors (partial predictions, corrected for the effects of other predictors; model M5)
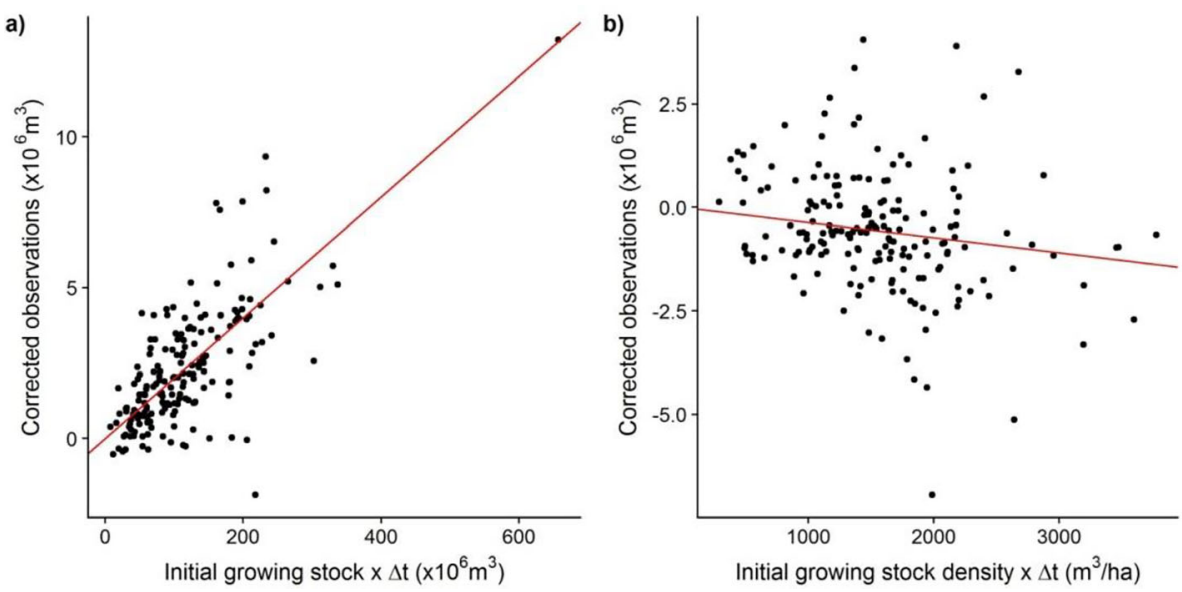

\section{Annex 10}

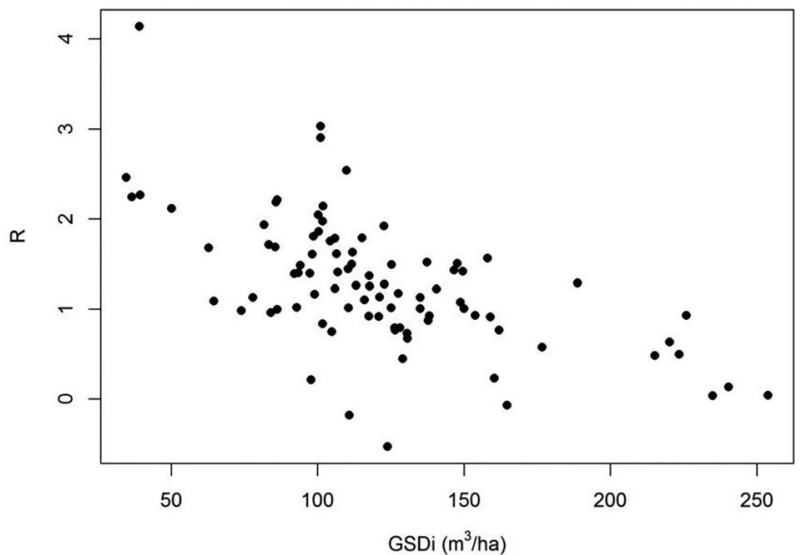

Fig. 9 Cross-dau relationship between initial growing stock density $\left(\mathrm{GSD}_{\mathrm{i}}\right.$ of dau unit i) and the intensity of GS changes ( $R$ ratio, see "sections 2 and 2.3) 


\section{References}

Abadie J, Dupouey JL, Avon C, Rochel X, Tatoni T, Bergès L (2017) Forest recovery since 1860 in a Mediterranean region: drivers and implications for land use and land cover spatial distribution. Landsc Ecol 33(2):289-305

Barreiro S, Schelhaas M-J, McRoberts RE, Kändler G (2017) Forest inventory-based projection systems for wood and biomass availability. Springer, Heidelberg, Germany, Dordrecht, Netherland, London, United Kingdom, New York, United States

Berryman AA (1992) The origins and evolution of predator-prey theory. Ecology 73(5):1530-1535

Boisvenue C, Running S (2006) Impacts of climate change on natural forest productivity - evidence since the middle of the 20th century. Glob Chang Boil 12(5):862-882. https://doi.org/10.1111/j.13652486.2006.01134.x

Bontemps JD, Hervé JC, Leban JM, Dhôte JF (2011) Nitrogen footprint in a long-term observation of forest growth over the twentieth century. Trees 25(2):237-251

Boutefeu B (2005) L'aménagement forestier en France : à la recherché d'une gestion durable à travers 1'histoire. VertigO-la revue électronique en sciences de l'environnement 6(2)

Chakir R, Madignier AC (2006) Analyse des changements d'occupation des sols en France entre 1992 et 2003. Economie Rurale 296:59-68. https://doi.org/10.4000/economierurale.1920

Charru M, Seynave I, Herve JC, Bertrand R, Bontemps JD (2017) Recent growth changes in Western European forests are driven by climate warming and structured across tree species climatic habitats. Ann For Sci 74(33):34. https://doi.org/10.1007/s13595-017-0626-1

Ciais P, Reichtein M, Viovy N, Granier A, Ogée J, Allard V, Aubinet $\mathrm{M}$, Buchmann $\mathrm{N}$ et al (2005) Europe-wide reduction in primary productivity caused by the heat and drought in 2003. Nature 437: 529-533

Ciais P, Schelhaas MJ, Zaehle S, Piao SL, Cescatti A, Liski J, Luyssaert S, Le-Maire G, Bouriaud O, Freibauer A, Valentini R, Nabuurs GJ (2008) Carbon accumulation in European forests. Nat Geosci 1: 425-429. https://doi.org/10.1038/ngeo233

Cinotti B (1996) Evolution des surfaces boisées en France: proposition de reconstitution depuis le début du XIXe siècle. Revue Forestière Française 48(6):547-562. https://doi.org/10.4267/2042/26776

Cornwall W (2016) Efforts to link climate change to severe weather gain ground. Science 351:1249-1250

Coudun C, Gégout JC (2005) Ecological behaviour of herbaceous forest species along a $\mathrm{pH}$ gradient: a comparison between oceanic and semicontinental regions in northern France. Glob Ecol Biogeogr 14:263-270. https://doi.org/10.1111/j.1466-822X.2005.00144.x

Daubree L (1912) Statistique et Atlas des forêts de France. Paris, France, 2 vol

de Galbert M, Magrum M, Morin GA (2015) Valorisation agricole et forestière de l'espace rural - Rapport no14064, Ministère de l'agriculture, de l'agroalimentaire et de la forêt/CGAAER, 165p

Dedrick S, Spiecker H, Orazio C, Tome M (2007) Martinez, I. Plantation or conversion - the debate! European Forest Institute, Joensuu, Finland

Denardou A (2019) Changements du stock de bois sur pied des forêts françaises : description, analyse et simulation sur des horizons temporels pluri-décennal (1975 - 2015) et séculaire à partir des données de l'inventaire forestier national et de statistiques anciennes. $\mathrm{PhD}$ dissertation, Université de Lorraine (in French). http://www. theses.fr/2019LORR0009

Denardou A, Hervé JC, Dupouey JL, Bir J, Audinot T, Bontemps JD (2017) L'expansion séculaire des forêts françaises est dominée par l'accroissement du stock sur pied et ne sature pas dans le temps. Revue Forestière Française 69(4-5):319-339
Dodane C (2009) Les nouvelles forêts du Massif Central: enjeux sociétaux et territoriaux. Ces hommes qui plantaient des résineux pour éviter la friche, $\mathrm{PhD}$ thesis, Ecole normale supérieure Lettres et Sciences Humaines - ENS Lyon

Dupouey JL, Pignard G, Hamza N, Dhôte JF (2010) Estimating carbon stocks and fluxes in forest biomass: 2. Application to the French case based upon National Forest Inventory data. In: Loustau D (ed) Forests, carbon cycle and climate change. Quae, Paris, France, pp 101-129 ISBN 978-2-7592-0384-0

Egnell G, Laudon H, Rosvall O (2011) Perspectives on the potential contribution of Swedish forests to renewable energy targets in Europe. Forests 2(2):578-589. https://doi.org/10.3390/f2020578

European commission (2015) Sustainable agriculture, forestry and fisheries in the bioeconomy - a challenge for Europe. $4^{\text {th }}$ SCAR Foresight Exercise, 137p

FAO (2004) Global forest resources assessment update 2005: terms and definitions (final version). Forest Resources Assessment Programme Working Paper 83/E, FAO Forestry Department: Rome, Italy

FAO (2015) Global forest resources assessment 2015. Rome, Italy

Fjellstad WJ, Dramstad WE (1999) Patterns of change in two contrasting Norwegian agricultural landscapes. Landsc Urban Plan 45:177-191

Forest Europe (2015) Full state of Europe's forests 2015. Ministerial conference on the protection of forests in Europe, Madrid, Spain

Glatzel G (1999) Historic forest use and its possible implications to recently accelerated tree growth in Central Europe. In: Karjalainen T, Spiecker H, Laroussinie O (eds) Causes and consequences of accelerating tree growth in Europe, EFI Proceedings 27, European Forest Institute, Joensuu, Finland, pp. 65-74

Gregow H, Laaksonen A, Alper M (2017) Increasing large scale windstorm damage in western, central and northern European forests, 1951-2010. Sci Rep 7:46397. https://doi.org/10.1038/srep46397

Hall R, Smolkers R, Ernsting A, Lovera S, Alvarez I (2012) Bio-economy versus biodiversity, Global forest coalition report, $18 \mathrm{pp}$

Henttonen H, Nöjd P, Mäkinan H (2017) Environment-induced growth changes in the Finnish forests during 1971-2010 - an analysis based on National Forest Inventory. For Ecol Manag 386(15):22-36

Hervé JC (2016) France. In: Vidal C, Alberdi I, Hernández L, Redmond J (eds) National Forest Inventories. Springer, Cham, Switzerland, pp 385-404. https://doi.org/10.1007/978-3-319-44015-6 ISBN: 978-3319-44014-9

Hervé JC, Wurpillot S, Vidal C, Roman-Amat B (2014) L'inventaire des ressources forestières en France: un nouveau regard sur de nouvelles forêts. Revue Forestière Française 66(3):247-260. https://doi.org/ $10.4267 / 2042 / 56055$

Houghton RA, Hackler JL, Lawrence KT (1999) The U.S. carbon budget: contributions from land-use change. Sci 285(5427):574-578

Hüffel G (1927) Les méthodes de l'aménagement forestier en France. Annales de l'école nationale des eaux et forêts et de la station de recherches et expériences 1(2):1-230

IFN (2009) Tempête Klaus du 24 Janvier 2009: 234000 hectares de forêt affectés à plus de $40 \% 42,5$ millions de mètres cubes de dégât. L'IF 21:0-12

Kahle HP, Karjalainen T, Schuck A, Ågren GI, Kellomäki S, Mellert L, Prietzel J, Rehfuess KE, Spiecker H (2008) Causes and consequences of forest growth trends in Europe - results of the recognition project, European Forest Research Institute - Research Report $\mathrm{n}^{\circ}$ 21. Brill: Leiden, Netherlands, Boston, United-States, Köln, Germany. ISBN: 9789004167056

Karjalainen T, Pussinen A, Liski J, Nabuurs GJ, Eggers T, Lapveteläinen T, Kaipainen T (2003) Scenario analysis of the impacts of forest management and climate change on the European forest sector carbon budget. For Policy Econ 5(2):141-155

Kauppi PE, Ausubel JH, Fang J, Mather AS, Sedjo RA, Waggoner PE (2006) Returning forests analyzed with the forest identity. PNAS 103(46):17574-17579. https://doi.org/10.1073/pnas.0608343103 
Kauppi PE, Sandström V, Lipponen A (2018) Forest resources of nations in relation to human well-being. PLoS One 13:e0196248

Keenleyside C, Tucker GM (2010) Farmland abandonment in the EU: an assessment of trends and prospects. Report prepared for WWF. Institute for European Environmental Policy, London

Kennedy JJ, Dombeck MP, Koch NE (1998) Values, beliefs and management of public forests in the Western world at the close of the twentieth century. Unasylva 49:16-26

Koerner W, Dupouey JL, Dambrine E, Benoît M (1997) Influence of past land use on the vegetation and soils of present day forest in the Vosges mountains, France. J Ecol 85(3):351-358

Lasanta T, Arnaez J, Pascual N, Ruiz-Flano P, Errea MP, Lana-Renault N (2017) Space-time process and drivers of land abandonment in Europe. Catena 149(3):810-823

Le Noë J, Matej S, Magerl A, Bhan M, Erb K-H, Gingrich S (2020) Modeling and empirical validation of long-term carbon sequestration in forests (France, 1850-2015). Glob Chang Biol 26:24212434. https://doi.org/10.1111/gcb.15004

Levers C, Verkerk PJ, Müller D, Verburg PH, Butsic V, Leitão PJ, Lindner M, Kuemmerle T (2014) Drivers of forest harvesting intensity patterns in Europe. For Ecol Manag 315:160-172. https://doi. org/10.1016/j.foreco.2013.12.030

Li P, Zhu J, Hu H, Pan Y, Birdsey R, Fang J (2016) The relative contributions of forest growth and areal expansion to forest biomass carbon. Biogeosciences 13:375-388. https://doi.org/10.5194/bg-13375-2016

Loran C, Ginzler C, Bürgi M (2016) Evaluating forest transition based on a multi-scale approach: forest area dynamics in Switzerland 1850 2000. Reg Environ Chang 16(6):1807-1818. https://doi.org/10. 1007/s10113-015-0911-1

Luyssaert S, Schulze E, Börner A et al (2008) Old-growth forests as global carbon sinks. Nature 455:213-215. https://doi.org/10.1038/ nature 07276

MacDonald D, Crabtree JR, Wiesinger G, Dax T, Stamou N, Fleury P, Gutierrez Lazpita J, Gibon A (2000) Agricultural abandonment in mountain areas of Europe: environmental consequences and policy response. J Environ Manag 59:47-69

Marey-Pérez MF, Rodriguez-Vicente V (2008) Forest transition in northern Spain: local responses on large-scale programmes of field afforestation. Land Use Policy 26:139-156

Mather AS (1992) The forest transition. Area 24(4):367-379

Mather AS (2001) The transition from deforestation to reforestation in Europe. In: Angelsen A, Kaimowitz D (eds) Agricultural technologies and tropical deforestation. CABI Publishing, Oxon, New York, pp 35-52 ISBN: 0851994512

Mather AS, Fairbairn J, Needle CL (1999) The course and drivers of the forest transition: the case of France. J Rural Stud 15(1):65-90. https://doi.org/10.1016/S0743-0167(98)00023-0

McKechnie J, Colombo S, Chen J, Mabee W, Maclean HL (2011) Forest bioenergy or Forest carbon? Assessing trade-offs in greenhouse gas mitigation with wood-based fuels. Environ Sci Technol 45:789-795

Meyfroidt P, Lambin F (2011) Global forest transition: prospects for an end to deforestation. Annu Rev Environ Resour 36:343-371

Millar CI, Stephenson NL, Stephen SL (2007) Climate change and forests of the future: managing in the face of uncertainty. Ecol Appl 17: 2145-2151

Ministère de l'agriculture (2005) Indicators for the sustainable management of French forests

Nabuurs GJ, Lindner M, Verkerk PJ, Gunia K, Deda P, Michalak R, Grassi G (2013) First signs of carbon sink saturation in European forest biomass. Nat Clim Chang 3:792-796. https://doi.org/10.1038/ NCLIMATE1853

Normandin D (1979) Evolution de la structure des forêts françaises de 1910 à 1970. Essai d'analyse de l'évolution de la répartition des propriétés forestières privées par classes de surface. Revue
Forestière Française 31(3):235-252. https://doi.org/10.4267/ $2042 / 21284$

Petucco C, Abildtrup J, Stenger A (2015) Influences of nonindustrial private forestlandowners' management priorities on the timber harvest decision - a case study in France. J For Econ 21:152-166

Pignard G (2000) Evolution récente des forêts françaises: surface, volume sur pied, productivité. Revue Forestière Française 52 (sp.):27-36. https://doi.org/10.4267/2042/5404

Pourtet J (1972) L'évolution dans le choix des essences de reboisement. Revue Forestière Française 24 (sp.):567-575. https://doi.org/10. 4267/2042/20666

Prechtel A, von Lützow M, Schneider BU, Bens O, Bannick CG, KögelKnabner I, Hüttl RF (2009) Organic carbon in soils of Germany: status quo and the need for new data to evaluate potentials and trends of soil carbon sequestration. J Plant Nutr Soil Sci 172:601-614

Pulla P, Schuck A, Verkerk PJ, Lasserre B, Marchetti M, Green T (2013) Mapping the distribution of forest ownership in Europe. EFI technical report 88, $91 \mathrm{pp}$. https://www.efi.int/sites/default/files/files/ publication-bank/2018/tr_88.pdf

R Core Team (2017) R: A language and environment for statistical computing. R Foundation for statistical computing, Vienna, Austria. URL https://www.R-project.org/

Rautiainen A, Wernick I, Waggoner PE, Ausubel JH, Kauppi PE (2011) A national and international analysis of changing forest density. PLoS One 6:e19577. https://doi.org/10.1371/journal.pone.0019577

Rhemtulla JM, Mladenoff DJ, Clayton MK (2009) Historical forest baselines reveal potential for continued carbon sequestration. PNAS 106(15):6082-6087

Rouault G, Candeau JN, Lieutier F, Nageleisen LM, Martin JC, Warzée $\mathrm{N}$ (2006) Effects of drought and heat on forest insect populations in relation to the 2003 drought in Western Europe. Ann For Sci 63: 613-624

Rudel TK, Schneider L, Uriarte M (2010) Forest transitions: an introduction. Land Use Policy 27(2):95-97

Sällnas O, Berger A, Räty M, Trubins R (2015) An area-based matrix model for uneven-aged forests. Forests 6:1500-1515

Schmithüsen F, Hirsch F (2010) Private forest ownership in Europe. UNECE, FAO. Geneva timber and forest study paper $26: 112 p$

Senf C, Pflugmacher D, Zhiqiang Y, Sebald J, Knorn J, Neumann M, Hostert P, Seidl R (2018) Canopy mortality has doubled in Europe's temperate forests over the last three decades. Nat Commun 9:4978

Smith B.W, Miles PD, Vissage JS, Pugh SA (2004) Forest resources of the United States, 2002, General Technical Report NC-241; North Central Research Station, St. Paul, United-States; 137p. https://doi. org/10.2737/NC-GTR-241

Strijker D (2005) Marginal lands in Europe - causes of decline. Basic Appl Ecol 6(2):99-106

Taccoen A, Piedallu C, Seynave I, Perez V, Gégout-Petit A, Nageleisen L-M, Bontemps J-D, Gégout J-C (2019) Background mortality drivers of European tree species: climate change matters. Proc R Soc B 286:20190386. https://doi.org/10.1098/rspb.2019.0386

Tomppo E, Gschwantner T, Lawrence M, McRoberts RE (2010) National Forest Inventories. Springer, Heidelberg, Germany, Dordrecht, Netherland, London, United Kingdom, New York, United States

Vanhala P, Repo A, Liski J (2013) Forest bioenergy at the cost of carbon sequestration? Curr Opin Environ Sustain 5:41-46

Verburg PH, van Berkel DB, van Doorn AM et al (2010) Trajectories of land use change in Europe: a model-based exploration of rural futures. Landscape Ecol 25:217-232. https://doi.org/10.1007/s10980009-9347-7

Publisher's note Springer Nature remains neutral with regard to jurisdictional claims in published maps and institutional affiliations. 